\title{
Effect on Mechanical and Thermal Properties of Random Copolymer Polypropylene/Microcrystalline Cellulose Composites Using T-ZnOw as an Additive
}

\author{
Dan Cheng, Xiucheng Zhang $\mathbb{D}^{\mathbb{D}}$, Siyu Wang, and Lihua Liu \\ College of Science, Northeast Forestry University, Harbin, China \\ Correspondence should be addressed to Xiucheng Zhang; xiuchengzhang@nefu.edu.cn
}

Received 10 August 2018; Accepted 8 May 2019; Published 29 May 2019

Academic Editor: Avraam I. Isayev

Copyright (C) 2019 Dan Cheng et al. This is an open access article distributed under the Creative Commons Attribution License, which permits unrestricted use, distribution, and reproduction in any medium, provided the original work is properly cited.

Four-needle zinc oxide whisker ( $\mathrm{T}-\mathrm{ZnOw})$ incorporated into microcrystalline cellulose/maleic anhydride grafted polypropylene/random copolymer polypropylene (MCC/PP-g-MA/rPP) composite was prepared by melt blending. $5 \mathrm{wt} \% \mathrm{PP}-\mathrm{g}-\mathrm{MA}$ was used as a coupling agent to improve the interfacial compatibility between fillers and rPP. The effect of T-ZnOw on MCC/PP-g$\mathrm{MA} / \mathrm{rPP}$ composite was investigated by mechanical testing, thermogravimetric analysis (TGA), differential scanning calorimetry (DSC), and scanning electron microscopy (SEM). Addition of T-ZnOw enhanced the mechanical properties of composites with tensile and flexural strengths increasing by $10 \%$ and $6 \%$, respectively. SEM studies showed an improvement in the compatibility of fracture surfaces, which was evident from the absence of gaps between fillers and rPP. Additionally, initial thermal decomposition temperature and maximum weight loss temperature of T-ZnOw/MCC/PP-g-MA/rPP composite were both higher than those of MCC/PP-g-MA/rPP composite. Thermal degradation kinetics suggested that T-ZnOw has a weak catalytic effect on MCC, resulting in the early degradation of MCC and adhesion to the surface of rPP. Because of the presence of inorganic whiskers, the remaining weight percent was more than that of other composites at the end of the reaction. Crystallization temperature of the $\mathrm{T}-\mathrm{ZnOw} / \mathrm{MCC} / \mathrm{PP}-\mathrm{g}-\mathrm{MA} / \mathrm{rPP}$ composite was almost $3 \sim 5^{\circ} \mathrm{C}$ higher than that of MCC/PP-g-MA/rPP composite and close to the crystallization temperature of pure rPP.

\section{Introduction}

Polypropylene (PP) has been widely used for its high thermal stability, low density, low-cost, and recyclability [14]. However, PP suffers from insufficient rigidity at high temperatures and high brittleness at low temperatures. These shortcomings are typically overcome by methods like filling, blending, and reinforcing modification [5-9]. Among these approaches, filling modification is the most common method. In previous researches, fillers such as talc and calcium carbonate have been used to modify PP [10-15]. Recently, natural cellulose has been used as filler due to not only ease of availability, but also being biodegradable and environmentfriendly. Natural cellulose is widely used as reinforcement, like cotton, coconut shell, bagasse, hemp, and wood flour [16-23]. In addition to natural cellulose, microcrystalline cellulose (MCC) has also been widely applied in polymer reinforcement, owing to its large length diameter ratio and biodegradability. MCC also has the advantages of high elastic modulus, high rigidity, high crystallinity, and high mechanical properties like strength. Due to these properties, it has been used to prepare low-cost polymer composites which have high strength [24-27]. Inorganic whiskers, including zinc oxide, titanates, magnesium oxysulfate, and calcium sulfate, have also been used as reinforcement to improve the properties of thermoplastic polymers [28-33]. For example, four-needle zinc oxide whisker $(\mathrm{T}-\mathrm{ZnOw})$ is widely used for its unique three-dimensional structure and bacteriostatic, antistatic, and abrasion resistance properties [34-37]. Due to the structural feature of $\mathrm{T}-\mathrm{ZnOw}$, it has been used to prepare composites with isotropy rather than anisotropy [38]. PP used in the previous studies was mostly isotactic polypropylene (iPP) or recycled waste polypropylene ( $\mathrm{r}-\mathrm{PP}$ ). This PP generally has a high processing temperature, which 
would decompose cellulose. Therefore, in this paper, lowmelting random copolymer polypropylene ( $\mathrm{rPP}$ ) is studied by filling, in order to prevent the decomposition of cellulose.

Mixing or blending of MCC/T-ZnOw and rPP can lead to inhomogeneity and incompatibility problems. Hence, maleic anhydride grafted polypropylene (PP-g-MA) usually serves as a coupling agent. Since there are many polyhydroxy groups around the surface of MCC and T-ZnOw, they impart a polar nature to MCC and T-ZnOw. Thermoplastic polymers such as $\mathrm{rPP}$ are typically nonpolar in nature. In contrast, PP-g-MA can form a covalent bond with the hydroxyl groups of MCC or $\mathrm{T}-\mathrm{ZnOw}$ and the nonpolar group of rPP, thus improving the compatibility of composites [39, 40].

In this work, $\mathrm{T}-\mathrm{ZnOw} / \mathrm{MCC} / \mathrm{PP}-\mathrm{g}-\mathrm{MA} / \mathrm{rPP}$ composite was prepared for the first time and obtained by melt blending. It was proved that mechanical properties and thermal behavior of T-ZnOw mixed with MCC as fillers in rPP based composites determine the optimal $\mathrm{T}-\mathrm{ZnOw}$ mixing fraction. The prepared composite was characterized for mechanical properties by RGT-20A mechanical tester, morphological properties by SEM, and thermal behaviors by TGA and DSC.

\section{Experimental}

2.1. Materials. Random copolymer polypropylene (rPP) grade FL7632L supplied by Polyolefins Co., Ltd., Singapore, with a melt flow rate (MFR) of $7 \mathrm{~g} \cdot(10 \mathrm{~min})^{-1}$ and a density of $0.9 \mathrm{~g} \cdot \mathrm{cm}^{-3}$. rPP was made of propene and ethane. Microcrystalline cellulose (MCC) grade 170218A was supplied by Tianli Pharmaceutical Excipient Company, Qufu, China, with an average diameter of $25 \mu \mathrm{m}$. Four-needle zinc oxide whiskers (T-ZnOw) were provided by Chengdu Crystal Technology Co., Ltd., China. The compatibilizer, maleic anhydride grafted polypropylene (PP-g-MA) code P613, was supplied by DuPont, USA, with a density of $0.903 \mathrm{~g} \cdot \mathrm{cm}^{-3}$.

2.2. Preparation of Composites. Firstly, rPP, PP-g-MA, MCC, and $\mathrm{T}-\mathrm{ZnOw}$ were dried in an oven for 4 hours at $80^{\circ} \mathrm{C}$ and $105^{\circ} \mathrm{C}$, respectively. All the raw materials were dried to minimize the moisture content. Then the raw materials of rPP, MCC, T-ZnOw, and PP-g-MA were mixed in the torque rheometer (RM-200C, Harbin Hapro Electrical Technology Co., Ltd., China). Both compositions of composites had been listed in Table 1. All the blends were mixed in the torque rheometer for $10 \mathrm{~min}$ with the speed of $50 \mathrm{r} \cdot \mathrm{min}^{-1}$ and then pressed into $4 \mathrm{~mm}$ thick sheet by flat press. Finally, all samples were cut by a saw and the size was $80 \mathrm{~mm} \times 10 \mathrm{~mm} \times 4 \mathrm{~mm}$ (length $\times$ width $\times$ thickness) for experiment. Both processing and the flat press temperatures were $165^{\circ} \mathrm{C}$.

2.3. Mechanical Properties. The tensile strength was measured by a RGT-20A mechanical tester (Shenzhen Reger Instrument Co., Ltd., China) at a speed of $10 \mathrm{~mm} \cdot \mathrm{min}^{-1}$ according to the standard ASTM D638. The flexural strength was measured by the same mechanical tester at a strain rate of $2 \mathrm{~mm} \cdot \mathrm{min}^{-1}$ followed by ASTM D790 method.

The notched Izod impact strengths were measured with a XJC-25D impact tester (Chengde Tester Machine Co., Ltd.,
China) under ASTM D256 method and the maximum impact energy was $1 \mathrm{~J}$. All samples were prefabricated with a notch of about $2 \mathrm{~mm}$ before testing.

All mechanical specimens were balanced at $23 \pm 2^{\circ} \mathrm{C}$ for 48 hours before testing and all tests were measured at this temperature. Each sample was measured five times to obtain an average value.

The stress-strain curves of composites were tested by a Linkam TST350 tensile hot stage (Linkam Scientific Instruments, Ltd., UK). The sizes of samples were $30 \mathrm{~mm} \times 10 \mathrm{~mm}$ $\times 0.5 \mathrm{~mm}$ (length $\times$ width $\times$ thickness). The test speed was $10 \mu \mathrm{m} \cdot \mathrm{s}^{-1}$ and measured at room temperature. The tensile data were collected and analyzed with the Linksys 32 software. The stress and strain in this study are both engineering stress and strain obtained from the tensile hot stage.

2.4. Density Determination. Density was measured by ASTM D 1895 standard [41]. The density of composites was calculated by the following formula:

$$
\rho\left(\mathrm{g} \cdot \mathrm{cm}^{-3}\right)=\frac{m}{V}
$$

where

$$
m \text { is the mass of fiber/matrix; }
$$

$V$ is the volume of fiber/matrix.

2.5. Void Content of Composites. For determining the voids of hybrid composites, ASTM-D-2734-70 method was used [42]. The void content was determined by the following formula, calculated by the theoretical and experimental density of the composites [41-43]:

$$
\text { Void content }=\frac{\rho_{\mathrm{ct}}-\rho_{\mathrm{ce}}}{\rho_{\mathrm{ct}}} \times 100 \%
$$

that

$$
\rho_{\mathrm{ct}}=\frac{100}{\mathrm{R} / \mathrm{D}+\mathrm{r} / \mathrm{d}}
$$

where

$$
\begin{aligned}
& R \text { is the mass ratio of resin in composite; } \\
& D \text { is the density of the resin matrix; } \\
& r \text { is the mass ratio of reinforcement in composite; } \\
& d \text { is the density of the reinforcement; } \\
& \rho_{\text {ct }} \text { is the theoretical density of composite; } \\
& \rho_{\text {ce }} \text { is the experimental density of composite. }
\end{aligned}
$$

2.6. Scanning Electron Microscopy. The morphologies of composites were investigated by scanning electron microscopy (SEM) with a JSM-7500F SEM (Japan Electronics Co., Ltd.) at an accelerating voltage of $5 \mathrm{kV}$. The samples were quenched in liquid nitrogen and plated with gold on the fracture surface before SEM observations. 
TABLE 1: Components and preparation of composites.

\begin{tabular}{|c|c|c|c|c|}
\hline Sample & $\mathrm{rPP}(\mathrm{wt} \%)$ & PP-g-MA (wt\%) & MCC (wt\%) & $\mathrm{T}-\mathrm{ZnOw}(\mathrm{wt} \%)$ \\
\hline $\mathrm{rPP}$ & 100 & - & - & - \\
\hline \multirow{5}{*}{$\mathrm{MCC} / \mathrm{rPP}$} & 70 & - & 30 & - \\
\hline & 60 & - & 40 & - \\
\hline & 50 & - & 50 & - \\
\hline & 40 & - & 60 & - \\
\hline & 30 & - & 70 & - \\
\hline \multirow{5}{*}{ MCC/PP-g-MA/rPP } & 65 & 5 & 30 & \\
\hline & 55 & 5 & 40 & - \\
\hline & 45 & 5 & 50 & - \\
\hline & 35 & 5 & 60 & - \\
\hline & 25 & 5 & 70 & - \\
\hline \multirow{4}{*}{ T-ZnOw/MCC/PP-g-MA/rPP } & 35 & 5 & 57 & 3 \\
\hline & 35 & 5 & 55 & 5 \\
\hline & 35 & 5 & 53 & 7 \\
\hline & 35 & 5 & 50 & 10 \\
\hline
\end{tabular}

2.7. Thermogravimetric Analysis. Thermal behavior was measured using a thermogravimetric analyzer instrument (PerkinElmer, Pyris 1, Inc., USA) with a temperature from 50 to $800^{\circ} \mathrm{C}$ at a heating rate of $10^{\circ} \mathrm{C} \cdot \mathrm{min}^{-1}$ in nitrogen atmosphere. The samples of thermal degradation behavior at a heating rate of $5,10,20,30$, and $50^{\circ} \mathrm{C} \cdot \mathrm{min}^{-1}$, respectively. About 5 8 mg of each sample was used for analysis.

2.8. Differential Scanning Calorimetry. The samples were weighted with a range of $3 \sim 5 \mathrm{mg}$, sealed in aluminum pans, and then tested by the differential scanning calorimeter (PerkinElmer, Pyris Diamond, USA) in nitrogen atmosphere. For nonisothermal crystallization, the samples were first heated from $-20^{\circ} \mathrm{C}$ to $200^{\circ} \mathrm{C}$ at a heating rate of $20^{\circ} \mathrm{C} \cdot \mathrm{min}^{-1}$, then maintained at $200^{\circ} \mathrm{C}$ for 5 mins to eliminate any thermal history, and finally cooled to $-20^{\circ} \mathrm{C}$ at various cooling rates of $10,20,30,40$, and $50^{\circ} \mathrm{C} \cdot \mathrm{min}^{-1}$, respectively. Finally, the samples were heated from $-20^{\circ} \mathrm{C}$ to $200^{\circ} \mathrm{C}$ with a heating rate of $20^{\circ} \mathrm{C} \cdot \mathrm{min}^{-1}$.

\section{Results and Discussion}

\subsection{Mechanical Properties}

3.1.1. Mechanical Properties of $M C C / r P P$ Composite with or without PP-g-MA. Mechanical properties of MCC/PPg-MA/rPP composite and MCC/rPP composite are compared in Figures 1(a)-1(d). A significant improvement can be observed in the mechanical properties of MCC/PP-g$\mathrm{MA} / \mathrm{rPP}$ composite. The increase of tensile strength was due to maleic anhydride groups reacting with the hydroxyl groups of microcrystalline cellulose [44], thereby decreasing the agglomeration of cellulose and PP-g-MA. In this way, MCC can be entangled and dispersed in rPP matrix. This result has also been confirmed by SEM. The flexural strength and flexural modulus of blends increased with the presence of filler in matrix because of the high rigidity of fillers. In addition, the stress transmission between the matrix resin and fibers improved, which was consistent with the results of previous reports [45-47].

From the stress-strain curves (Figure 2(a)), it is evident that the fracture mode of the composite changed from ductile fracture to brittle fracture, in the presence of fillers. The fillers also enhanced the rigidity of the matrix and decreased its toughness. The decrease in elongation at break was mainly affected by fillers [48]. In addition, the tensile modulus had an obvious increase (Figure 1) and its changes were higher than the expected values. Since cellulose has a high modulus, the interaction of maleic anhydride groups grafted onto PP chains with - $\mathrm{OH}$ groups of cellulose increases the adhesion between cellulose and matrix. When MCC content was $40 \mathrm{wt} \%$, the tensile modulus of the composite exhibited a maximum value. It can be seen from Figure 1 that with high loadings the mechanical properties of the composite still showed good performances. For example, when the MCC loading was $60 \mathrm{wt} \%$, the tensile strength of the composite was $25.59 \mathrm{MPa}$ which was similar to $\operatorname{rPP}(27.78 \mathrm{MPa})$. The flexural strength was $48.39 \mathrm{MPa}$ and improved by $54 \%$ as compared to pure $\mathrm{rPP}(31.23 \mathrm{MPa})$.

In the impact test, the presence of PP-g-MA could effectively resist the crack propagation due to higher interfacial adhesion. The impact strength increased along with the increase in fiber content. However, the trend of impact strength was increased firstly and then decreased, since the impact properties of fibers were lower than rPP. Filling more MCC tends to increase stress concentration of the materials, making the cracks more prominent. However, from the overall trend of mechanical properties in Figure 1, it could be seen that the mechanical properties of the composite with $60 \mathrm{wt} \%$ MCC were relatively stable. Since MCC is inexpensive, large filling could save cost without affecting the performance of the composite. Besides, MCC is biodegradable, which makes it more economical, environment-friendly, and useful as compared to pure PP. Therefore, MCC/PP-g-MA/rPP 

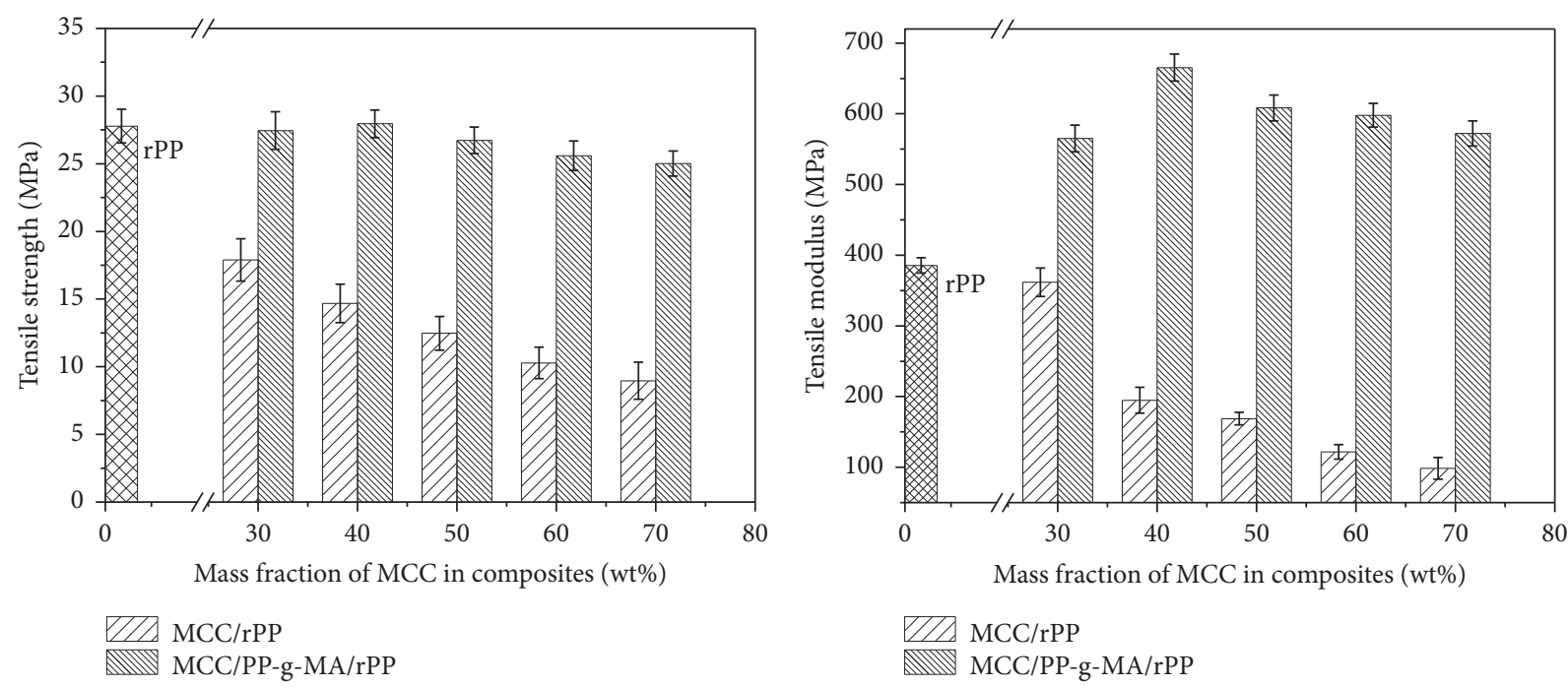

(a)

(b)
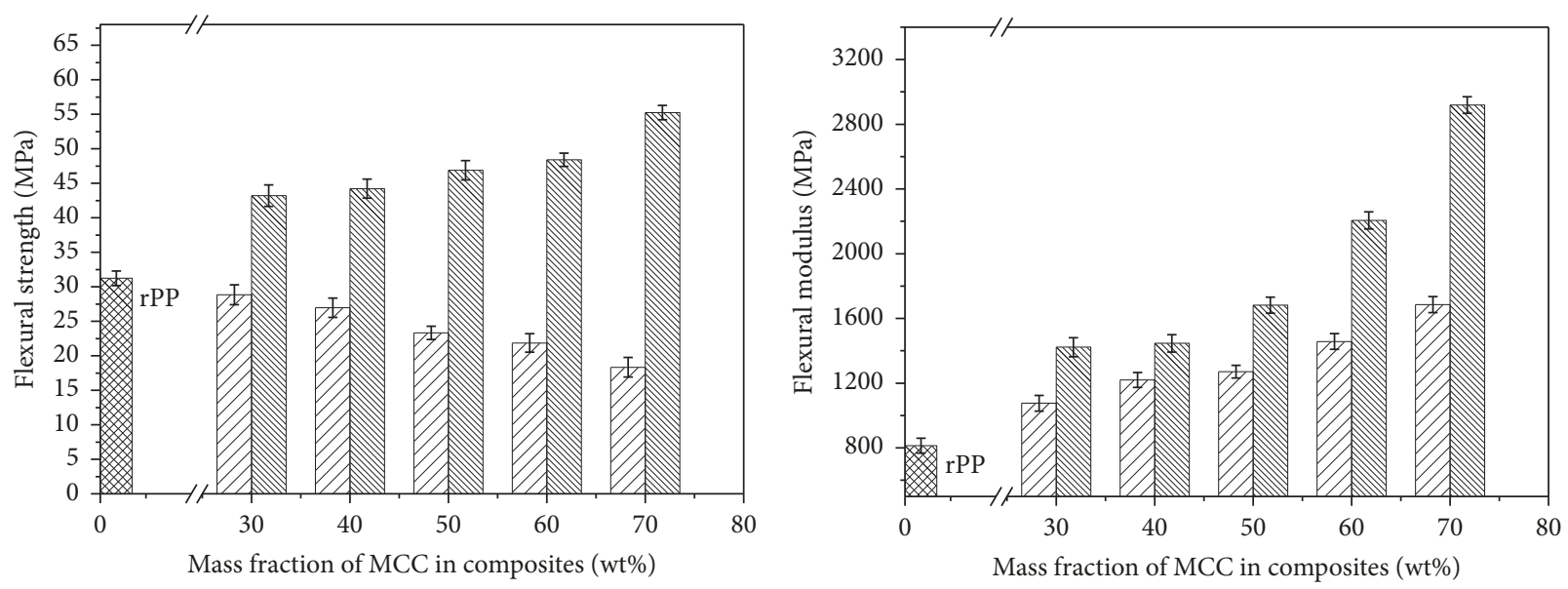

ZI/ MCC/rPP

$\mathbb{M}$ MCC/PP-g-MA/rPP

V/A MCC/rPP

$\mathbb{W}$ MCC/PP-g-MA/rPP

(c)

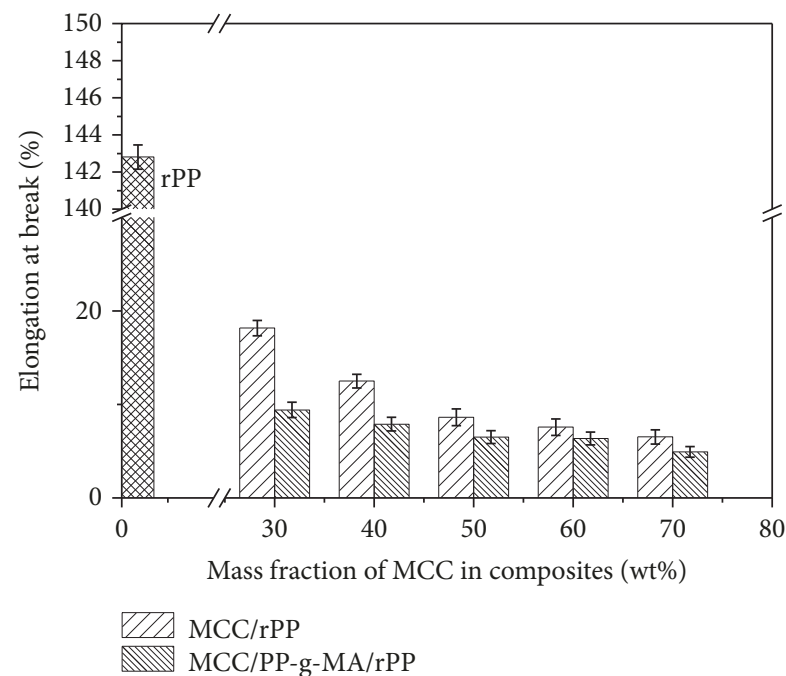

(e)

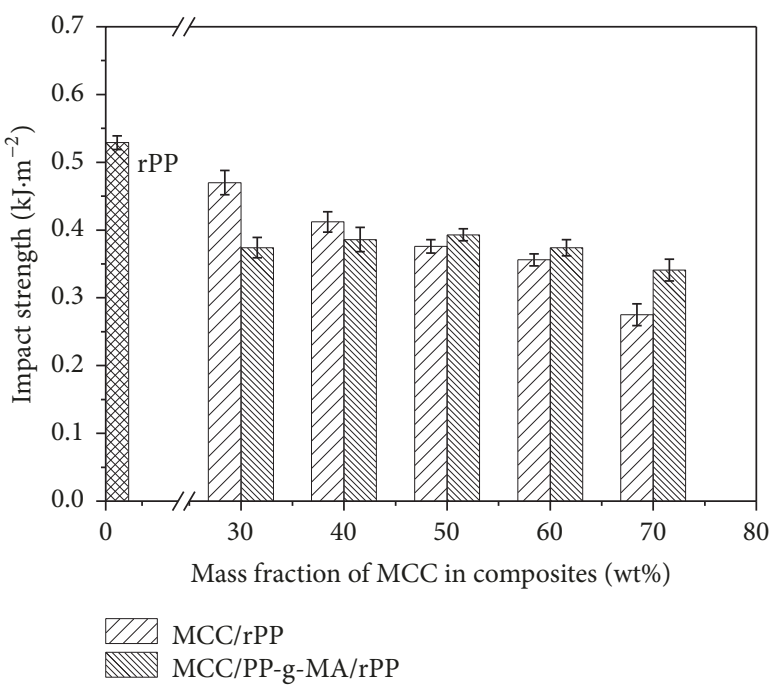

(f)

FIGURE 1: Influence of various MCC concentrations on the mechanical properties of composites. 


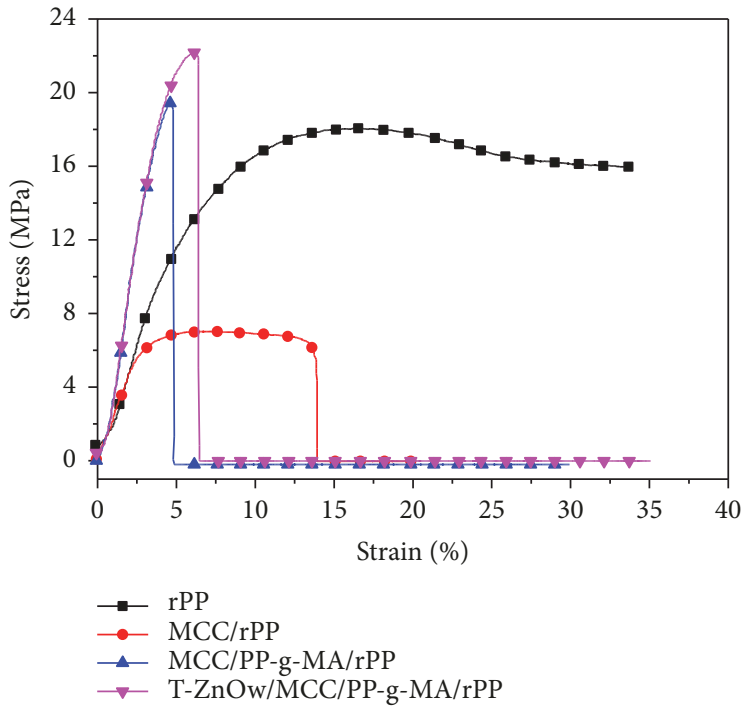

(a)

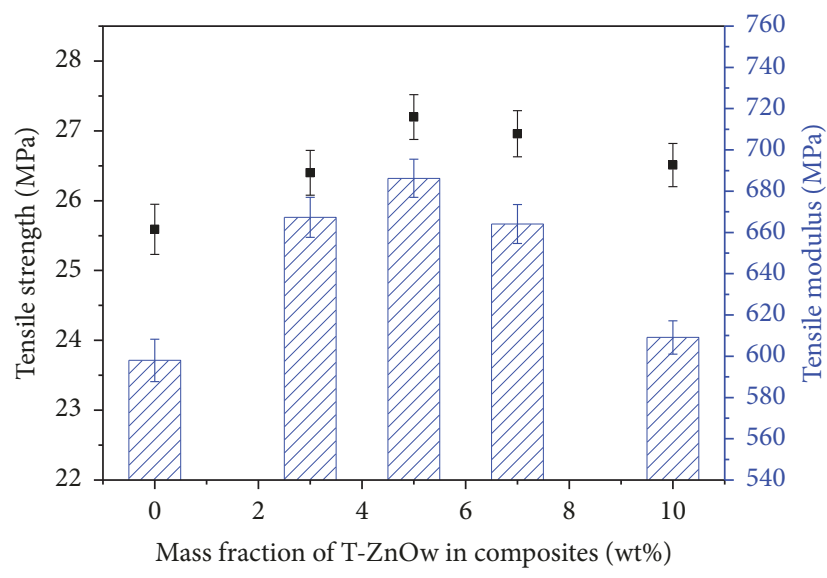

- Tensile strength

VIIA Tensile modulus

(b)

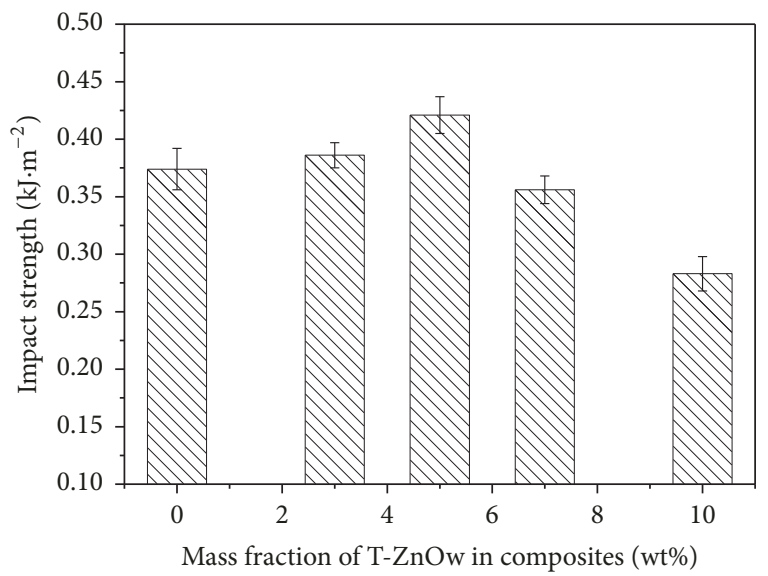

(d)

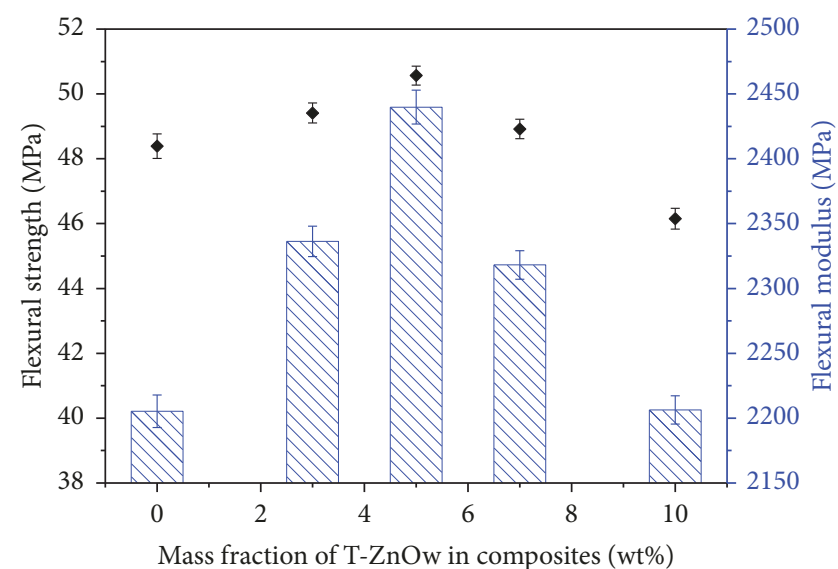

- Flexural strength

IIV Flexural modulus

(c)

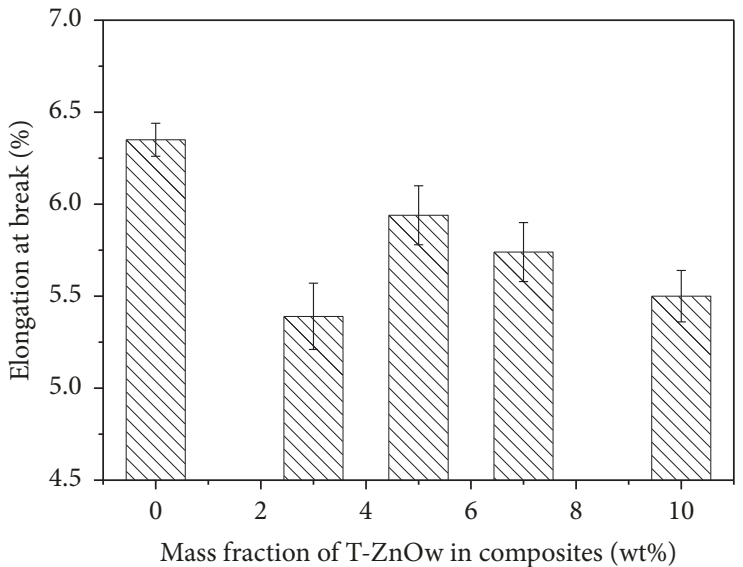

(e)

FiguRE 2: Stress-strain curves and influence of various T-ZnOw concentrations on the mechanical properties of T-ZnOw/MCC/PP-g$\mathrm{MA} / \mathrm{rPP}$ composite. 
TABLE 2: Density and void content of composites.

\begin{tabular}{|c|c|c|c|c|}
\hline Sample & $\begin{array}{c}\text { Weight Fraction } \\
(\%)\end{array}$ & $\begin{array}{c}\text { Experimental density } \\
\left(\mathrm{g} \cdot \mathrm{cm}^{-3}\right)\end{array}$ & $\begin{array}{l}\text { Theoretical density } \\
\left(\mathrm{g} \cdot \mathrm{cm}^{-3}\right)\end{array}$ & $\begin{array}{c}\text { Void conten } \\
(\%) \\
\end{array}$ \\
\hline \multirow{5}{*}{ MCC/PP-g-MA/rPP } & $30: 5: 65$ & 0.95 & 1.01 & 5.67 \\
\hline & $40: 5: 55$ & 0.97 & 1.03 & 5.83 \\
\hline & 50:5:45 & 1.03 & 1.11 & 7.21 \\
\hline & $60: 5: 35$ & 1.06 & 1.15 & 7.83 \\
\hline & $70: 5: 25$ & 1.07 & 1.17 & 8.55 \\
\hline \multirow{4}{*}{ T-ZnOw/MCC/PP-g-MA/rPP } & $3: 58: 5: 35$ & 0.99 & 1.22 & 18.85 \\
\hline & $5: 57: 5: 35$ & 0.93 & 1.15 & 19.13 \\
\hline & $7: 55: 5: 35$ & 0.87 & 1.12 & 22.32 \\
\hline & 10:53:5:35 & 0.81 & 1.11 & 27.03 \\
\hline
\end{tabular}

Specific gravity of the matrix $\rho_{1}=0.900 \mathrm{~g} \cdot \mathrm{cm}^{-3}$.

Specific gravity of the MCC $\rho_{2}=1.244 \mathrm{~g} \cdot \mathrm{cm}^{-3}$.

Specific gravity of the T-ZnOw $\rho_{3}=0.200 \mathrm{~g} \cdot \mathrm{cm}^{-3}$.

composite with mass ratio of $60 / 5 / 35$ was used in following experiments.

3.1.2. Mechanical Properties of $M C C / P P-g-M A / r P P C o m-$ posite with T-ZnOw. Mechanical properties of MCC/PP-g$\mathrm{MA} / \mathrm{rPP}$ composite with $\mathrm{T}-\mathrm{ZnOw}$ as additive are shown in Figures 2(b)-2(e), where they increased initially and then decreased with the increase of whisker fraction. When $\mathrm{T}-\mathrm{ZnOw}$ content was $5 \mathrm{wt} \%$, composite generally showed relatively good performance, as the optimal amount of $\mathrm{T}$ $\mathrm{ZnOw}$ had enhanced toughening effect on rPP, and the compatibilizer PP-g-MA had improved the interfacial compatibility between fillers and the matrix. More importantly, an appropriate amount of $\mathrm{T}-\mathrm{ZnOw}$ has a "nail" effect on the composite [49], and its three-dimensional structural features could act as a framework that could disperse the stress transmitted by the matrix resin, thereby hindering the formation of stress concentration points. Therefore, these two reinforcement fillers improved the mechanical properties of the composites as confirmed in Figure 2. On the other hand, due to the unique spatial three-dimensional structure of $\mathrm{T}-\mathrm{ZnOw}$, the impact energy of the composite could be absorbed. With further increase of the T-ZnOw, the mechanical properties of the composite showed a decreasing trend. This could be explained by the increasing of internal defects due to the high content of whiskers. Under external force, these defects promoted crack growth. Besides, the presence of $\mathrm{T}-\mathrm{ZnO}$ w could promote an increase in crystal size resulting in a decrease in mechanical properties. More importantly, when the content of $\mathrm{T}-\mathrm{ZnO}$ was higher, the fracture mode of the material changed from ductile fracture to brittle fracture and led to a reduction in mechanical properties [50]. Therefore, adding $5 \mathrm{wt} \% \mathrm{~T}-\mathrm{ZnOw}$ as reinforcing agent into $\mathrm{MCC} / \mathrm{PP}-\mathrm{g}-$ $\mathrm{MA} / \mathrm{rPP}$ composite was selected for best performance.

3.2. Density and Void Content of Composites. The theoretical and experimental densities of composites were shown in Table 2. In the MCC/PP-g-MA/rPP composites, it is clearly evident that the density of the composite is increasing with the increase of the MCC content. It is understandable as the specific gravity of matrix $\left(0.900 \mathrm{~g} \cdot \mathrm{cm}^{-3}\right)$ is less than MCC $\left(1.244 \mathrm{~g} \cdot \mathrm{cm}^{-3}\right)$. However, the density of T-ZnOw/MCC/PP$\mathrm{g}-\mathrm{MA} / \mathrm{rPP}$ composites is decreasing with the increase of T$\mathrm{ZnOw}$ content, as the density of $\mathrm{T}-\mathrm{ZnOw}$ is extremely low $\left(0.2 \mathrm{~g} \cdot \mathrm{cm}^{-3}\right)$.

The void content is the difference of theoretical and practical density of composites. During impregnating the fibers into the matrix or manufacturing the fiber reinforced composites, the trapped air or other volatiles exist in composites and make the void space. The voids were caused in this way, and this had been confirmed by some researchers $[51,52]$. The void contents (\%) of composites were presented in Table 2. It can be seen that the void content of composites increased with the increase of fillers. And the presence of the void in composites would reduce the mechanical and physical properties of composites [43].

In the MCC/PP-g-MA/rPP composites, the content of voids increased with the increase of MCC. When adding $60 \mathrm{wt} \% \mathrm{MCC}$, the void content was $7.83 \%$. The little void indicated that dispersion of MCC in matrix is well and the PP-g-MA still acts as compatibilizer. Foremost and little voids have little effect on the mechanical properties of composites.

In the $\mathrm{T}-\mathrm{ZnOw} / \mathrm{MCC} / \mathrm{PP}-\mathrm{g}-\mathrm{MA} / \mathrm{rPP}$ composite, the void content of the composite increases with the addition of $\mathrm{T}$ $\mathrm{ZnOw}$. Because of the fluffy morphology of $\mathrm{T}-\mathrm{ZnOw}$, much air would be trapped in the composite and form a gap during the manucaption of composites. When adding $5 \mathrm{wt} \%$ $\mathrm{T}-\mathrm{ZnOw}$, the void content of the composite was $19.13 \%$. When little $\mathrm{T}-\mathrm{ZnO}$ was added in composites, the unique spatial structure of $\mathrm{T}-\mathrm{ZnOw}$ could not be exhibited in the material. But when much $\mathrm{T}-\mathrm{ZnOw}$ is added, the crystallization size of the matrix would increase and weaken the mechanical properties of the composite. Therefore, MCC/PP-g-MA/rPP composites would have high mechanical properties after adding $5 \mathrm{wt} \% \mathrm{~T}-\mathrm{ZnOw}$ to it.

3.3. Morphological Properties. Figure 3 shows the SEM micrographs of the fracture surfaces of rPP based composites, with Figures 3(a) and 3(b) showing the microstructures of $5 \mathrm{wt} \% \mathrm{PP}-\mathrm{g}-\mathrm{MA} / \mathrm{rPP}$ composite. It is evident that the surface 


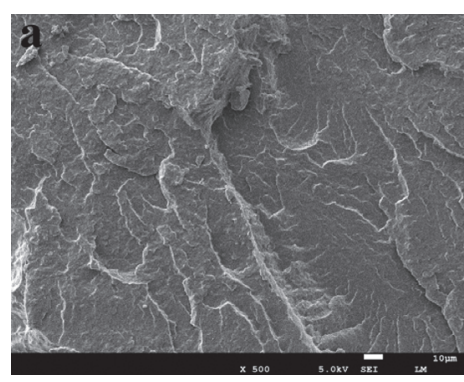

(a)

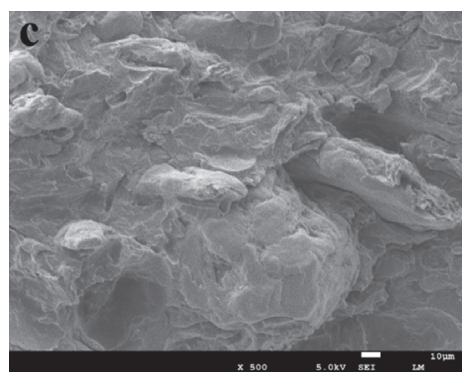

(c)

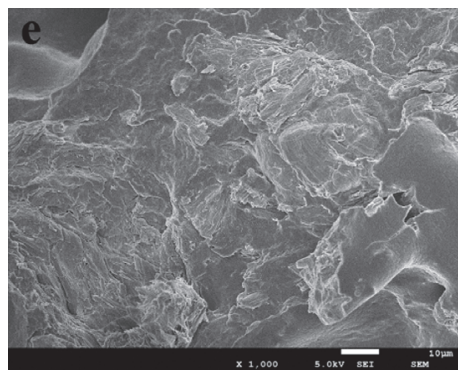

(e)

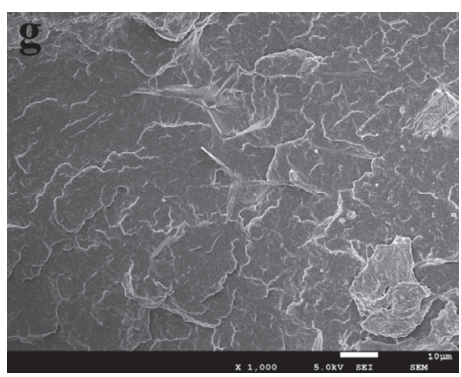

(g)

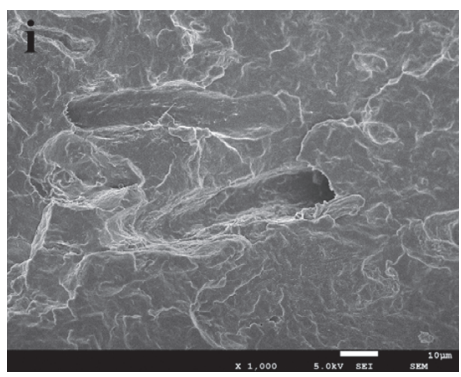

(i)

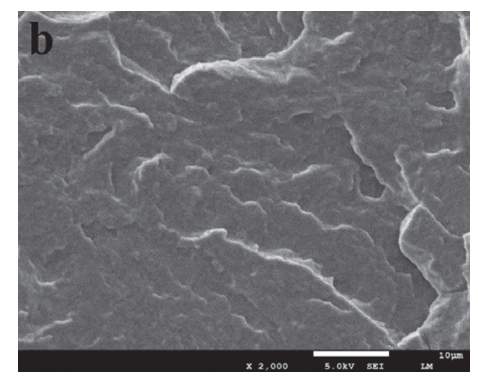

(b)

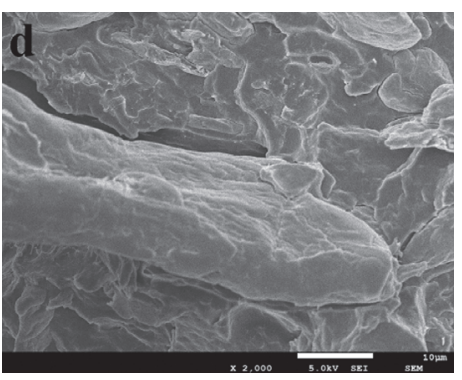

(d)

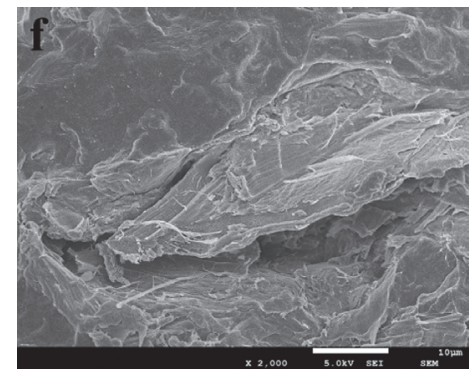

(f)

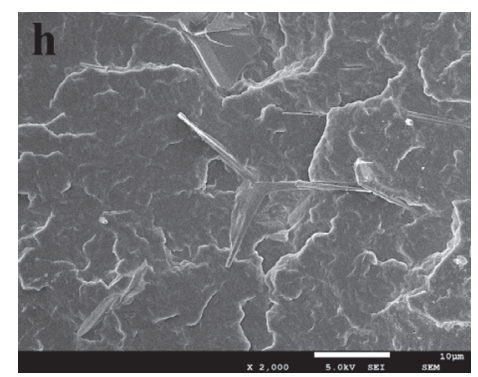

(h)

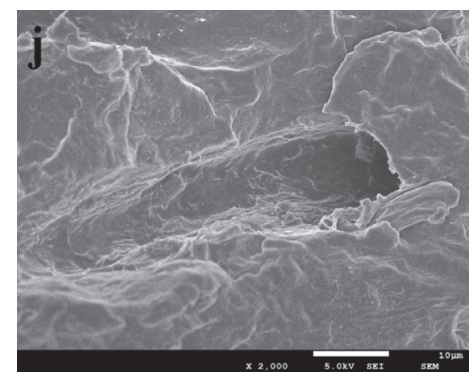

(j)

FiguRE 3: Fractured surface micrographs of rPP and its composites: (a-b) PP-g-MA/rPP (5/95); (c-d) MCC/rPP (60/40) (500× and 2000×); (ef) MCC/PP-g-MA/rPP (60/5/35); (g-h) T-ZnOw/PP-g-MA/rPP (5/5/90); (i-j) T-ZnOw/MCC/PP-g-MA/rPP (5/55/5/35) (1000× and 2000×). 

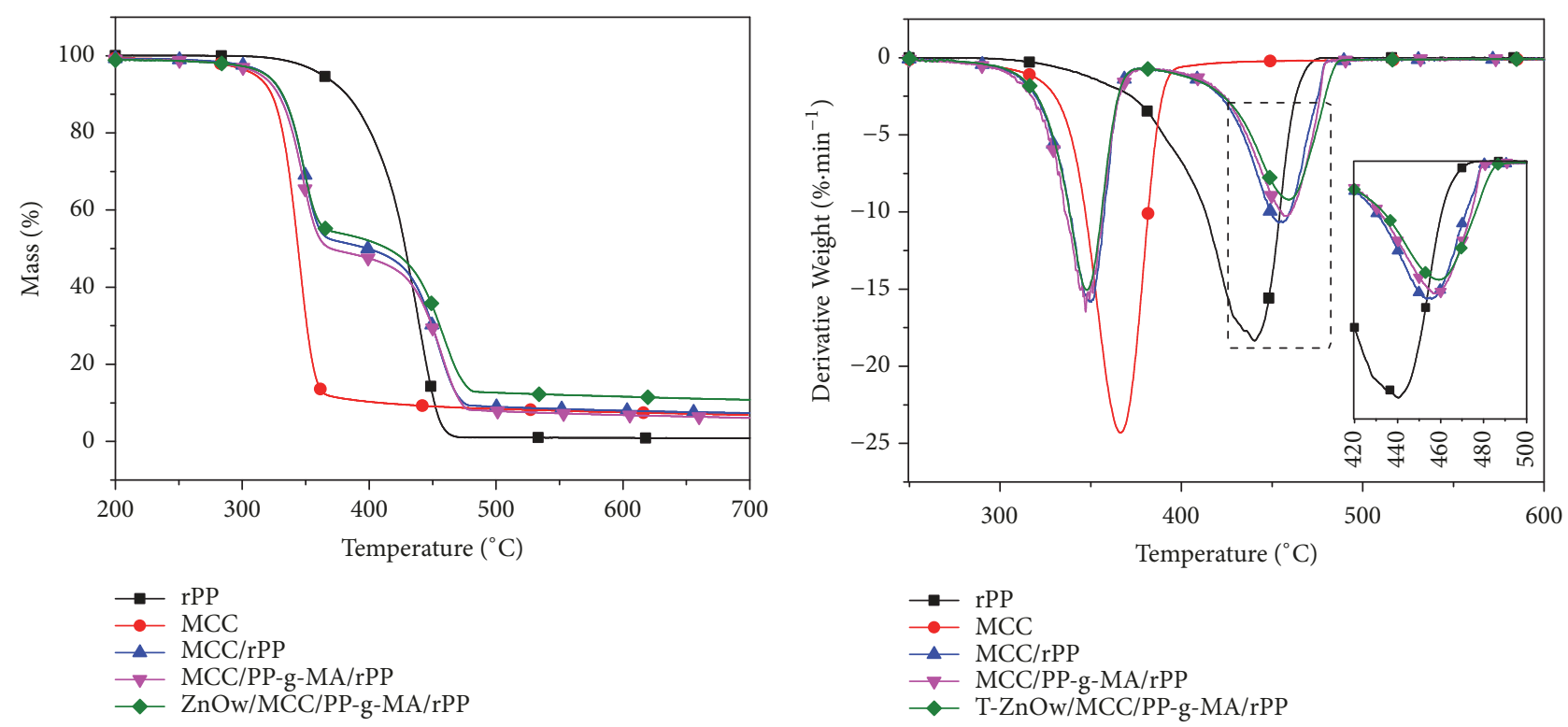

FIgURE 4: The TGA and DTG curves of MCC and rPP and the composites of MCC/rPP (60/40) and MCC/PP-g-MA/rPP (60/5/35) and T-ZnOw/MCC/PP-g-MA/rPP (5/55/5/35).

was very smooth after adding compatibilizer which indicated that the PP chains in PP-g-MA had been crosslinked with the matrix resin. The surface morphologies of $\mathrm{MCC} / \mathrm{rPP}$ composite are shown in Figures 3(c) and 3(d), where obvious boundaries and gaps can be observed between MCC and rPP. From the cross-section it is observed that fibers were pulled out, which indicates poor adhesion between the filler and the matrix along with low compatibility.

Figures 3(e) and 3(f) show the SEM micrographs of MCC/rPP composite with $5 \mathrm{wt} \% \mathrm{PP}-\mathrm{g}-\mathrm{MA}$. MCC at the cross-section was tightly bonded to matrix with no fiber pullout. This is because most of the MCC was embedded in the matrix resin and cellulose had been torn at the cross-section. This is attributed to PP-g-MA in the composite, which improved the adhesion and interface compatibility between the two phases. This result has been further corroborated in mechanical properties of $\mathrm{MCC} / \mathrm{PP}-\mathrm{g}-\mathrm{MA} / \mathrm{rPP}$ composite. Figures 3(g) and 3(h) show microscopic morphologies of $5 \mathrm{wt} \%-\mathrm{T}-\mathrm{ZnOw} / \mathrm{PP}-\mathrm{g}-\mathrm{MA} / \mathrm{rPP}$, where it is evident that whiskers were wrapped by the resin. This resulted in some white spots but no voids were formed. Since $\mathrm{T}-\mathrm{ZnOw}$ plays a "skeleton" role in the composite, the stress could be transmitted from the matrix resin to whiskers after being subjected to an external force. When the composite is subjected to a force, whiskers can hinder the propagation of cracks and change the direction of expansion of the material. The phenomenon of crack deflection increased the area of crack so that more energy would be absorbed when the composite was broken. Moreover, $\mathrm{T}-\mathrm{ZnOw}$ could be seen in the fracture surface as embedded in the matrix, which indicates that PP-g-MA also promoted the adhesion of the interface between the inorganic whisker T-ZnOw and rPP. The micrographs after adding $5 \mathrm{wt} \% \mathrm{~T}-\mathrm{ZnOw}$ in MCC/PP-g-MA/rPP composites are shown in Figures 3(i) and 3(j), where it can be observed
TABLE 3: Parameters of MCC and pure rPP and rPP based composites gotten from TGA.

\begin{tabular}{lccc}
\hline Sample & $T_{-5 \%}\left({ }^{\circ} \mathrm{C}\right)$ & $T_{1}\left({ }^{\circ} \mathrm{C}\right)$ & $T_{2}\left({ }^{\circ} \mathrm{C}\right)$ \\
\hline rPP & 363.3 & - & 440.2 \\
MCC & 310.4 & 367.0 & - \\
MCC/rPP & 319.3 & 349.8 & 454.5 \\
MCC/PP-g-MA/rPP & 314.8 & 347.1 & 457.3 \\
T-ZnOw/MCC/PP-g-MA/rPP & 319.1 & 347.9 & 460.1 \\
\hline
\end{tabular}

$T_{-5 \%}$ : initial decomposition temperature.

$T_{1}$ : the maximum weight loss temperature of MCC.

$T_{2}$ : the maximum weight loss temperature of $\mathrm{rPP}$.

that the body of whiskers was wrapped by the matrix resin even though some whisker needles were pulled out. Some rough cavities also remained but there was no obvious interface gap in the section.

3.4. Thermal Properties. The thermal behavior of MCC/rPP, MCC/PP-g-MA/rPP, pure rPP, MCC, and T-ZnOw/MCC/ $\mathrm{PP}-\mathrm{g}-\mathrm{MA} / \mathrm{rPP}$ composites is shown in Figure 4. Table 3 lists the initial degradation temperatures $\left(T_{-5 \%}\right)$ and maximum weight loss temperatures $\left(T_{1}, T_{2}\right)$ in the TGA and DTG curves. Only one decomposition process occurred in the pure rPP and MCC, as evident from the TGA curves. However, the TGA curves of rPP based composites showed two distinct decomposition stages. The first decomposition stage was in the range of $280-380^{\circ} \mathrm{C}$, which is attributed to cellulose, whereas the second decomposition stage occurred between 400 and $480^{\circ} \mathrm{C}$, mainly due to $\mathrm{PP}$ decomposition. $T_{-5 \%}$ and $T_{2}$ of pure $\operatorname{rPP}$ were $363.3^{\circ} \mathrm{C}$ and $440.2^{\circ} \mathrm{C}$, respectively. And the $T_{-5 \%}$ and $T_{1}$ of MCC were $310.4^{\circ} \mathrm{C}$ and $367.0^{\circ} \mathrm{C}$, respectively. It could be observed that the thermal stability 
TABLE 4: Ea parameters of rPP and rPP based composites.

\begin{tabular}{lcccc}
\hline$a(\%)$ & & & $\begin{array}{c}E a\left(\mathrm{~kJ} \cdot \mathrm{mol}^{-1}\right) \\
\text { MCC/PP-g-MA/rPP }\end{array}$ & T-ZnOw/MCC/PP-g-MA/rPP \\
\hline 5 & rPP & MCC/rPP & 194.0 & 181.0 \\
10 & 113.6 & 165.1 & 195.2 & 187.6 \\
20 & 123.3 & 182.0 & 198.3 & 193.2 \\
30 & 136.3 & 191.6 & 200.0 & 193.3 \\
40 & 149.6 & 191.4 & 197.3 & 196.2 \\
50 & 161.1 & 189.9 & 268.6 & 195.6 \\
60 & 168.6 & 267.2 & 245.5 & 146.2 \\
70 & 174.9 & 211.8 & 249.4 & 183.8 \\
80 & 181.9 & 241.9 & 264.6 & 219.3 \\
90 & 189.2 & 248.4 & 290.4 & - \\
\hline
\end{tabular}

of MCC was lower than rPP. However, when MCC was introduced into $\mathrm{rPP}$, the $T_{-5 \%}$ and $T_{2}$ of $\mathrm{rPP} / \mathrm{MCC}$ composite were improved and the $T_{1}$ was decreased. The initial decomposition temperature of the composite increased possibly due to the fiber protection function of PP although the interfacial bonding in MCC/rPP composite was a limiting factor. There were gaps around the fiber, which was beneficial to the diffusion of thermal decomposition products. This accelerated the decomposition rate of cellulose, so $T_{1}$ of the composite shifted to lower temperature. With the inclusion of PP-g-MA, $T_{-5 \%}$ of the composite was decreased, which could be affected by unreacted PP-g-MA or anhydride groups resulting in the degradation of cellulose during the reaction [53].

With the addition of $\mathrm{T}-\mathrm{ZnOw}$, the initial decomposition temperature of T-ZnOw/MCC/PP-g-MA/rPP (5/55/5/35) composite and the heat decomposition temperature of rPP shifted to a higher temperature, as evident from Figure 4 and Table 3 . The residue generated by the decomposition of cellulose existed on the surface of the matrix and played a hysteresis role in the decomposition process of the matrix. This resulted in an increase in the decomposition temperature of the matrix.

3.5. Thermal Degradation Kinetic Analysis. In order to further analyze the effect of fillers on the thermal degradation of polymers, thermal degradation kinetics studies were performed to analyze the following $\mathrm{rPP}$ based composites: pure rPP, MCC/rPP, MCC/PP-g-MA/rPP, and T-ZnOw/MCC/PPg-MA/rPP composites. Flynn-Wall-Ozawa (OFW) equation (4) was used to analyze thermal degradation of composites. The activation energy $(\mathrm{Ea})$ of composites was calculated from the temperature $T$ corresponding to the different weight loss rate $(\alpha)$ at different heating rates $(\beta)$. According to OFW, from the $\ln (\beta)$ versus $1000 / T$ plot, the slope of the line $(-E a / R)$ yields the thermal degradation activation energy $(E a)$ of pure rPP and its composites, as listed in Table 4.

$$
\ln (\beta)=\ln \left[\frac{A f(\alpha)}{\mathrm{d} \alpha / \mathrm{d} T}\right]-\frac{E \mathrm{a}}{R T}
$$

where $\beta$ is the heating rate, $\mathrm{K} \cdot \mathrm{min}^{-1}$; $A$ refers to the prefactor, $\min ^{-1}$; $\alpha$ is the composite material mass loss rate, \%;

$T$ is the temperature corresponding to certain $\alpha$ of the composite material, $\mathrm{K}$;

$R$ is gas constant.

$\ln (\beta) \sim 1000 / T$ (Figures 5(a)-5(d)) showed a good linear relationship at different conversion rates, which indicates that the results of the activation energy calculated by this method are reliable.

It can be observed from the Table 4 that the variation of values of Ea of composites corresponds to the two parts of thermal decomposition behavior, which is consistent with the TGA analysis. The thermal degradation activation energy of $\mathrm{MCC} / \mathrm{rPP}$ composite was higher than pure $\mathrm{rPP}$. When $\alpha$ is in the range from $5 \%$ to $40 \%$, the energy used for cellulose decomposition involved breaking the bond force, hydrogen bonding force between the molecules, and the Vander Waals force between cellulose and matrix. Hence, the energy consumption was high during the decomposition process. Ea of composites increased sharply when $\alpha$ was greater than $40 \%$, which may be due to the hindrance of the residue formed by the degradation of the cellulose during the decomposition of the polymer matrix. The Ea values of MCC/PP-g-MA/rPP composite with incorporation of compatibilizer were significantly higher, because the addition of PP-g-MA made MCC disperse evenly in the matrix, thereby reducing the gap. The interaction between MCC and PP became stronger and increased the bond energy, as corroborated by SEM. Therefore, the decomposition of MCC is unfavorable at low temperature, which enhanced the barrier of heat transfer and increased thermal stability along with thermal degradation activation energy of the composite. After adding $5 \mathrm{wt} \%$ $\mathrm{T}-\mathrm{ZnOw}$ in MCC/PP-g-MA/rPP composite, the activation energy of the composite was slightly reduced due to low density of $\mathrm{T}-\mathrm{ZnOw}$. It was the reason for the poor heat insulation ability of $\mathrm{T}-\mathrm{ZnO}$. The thermal degradation of composites had a catalytic effect, mainly manifested in the thermal degradation of MCC. However, at high temperature MCC could dehydrate to carbon and adhere to the surface of the polymer to form a dense insulating carbon layer to reduce the amount of heat transferred from the outside to the inside. When $\alpha$ was greater than $80 \%$, a larger residual amount of the polymer remained due to the inorganic filler. 

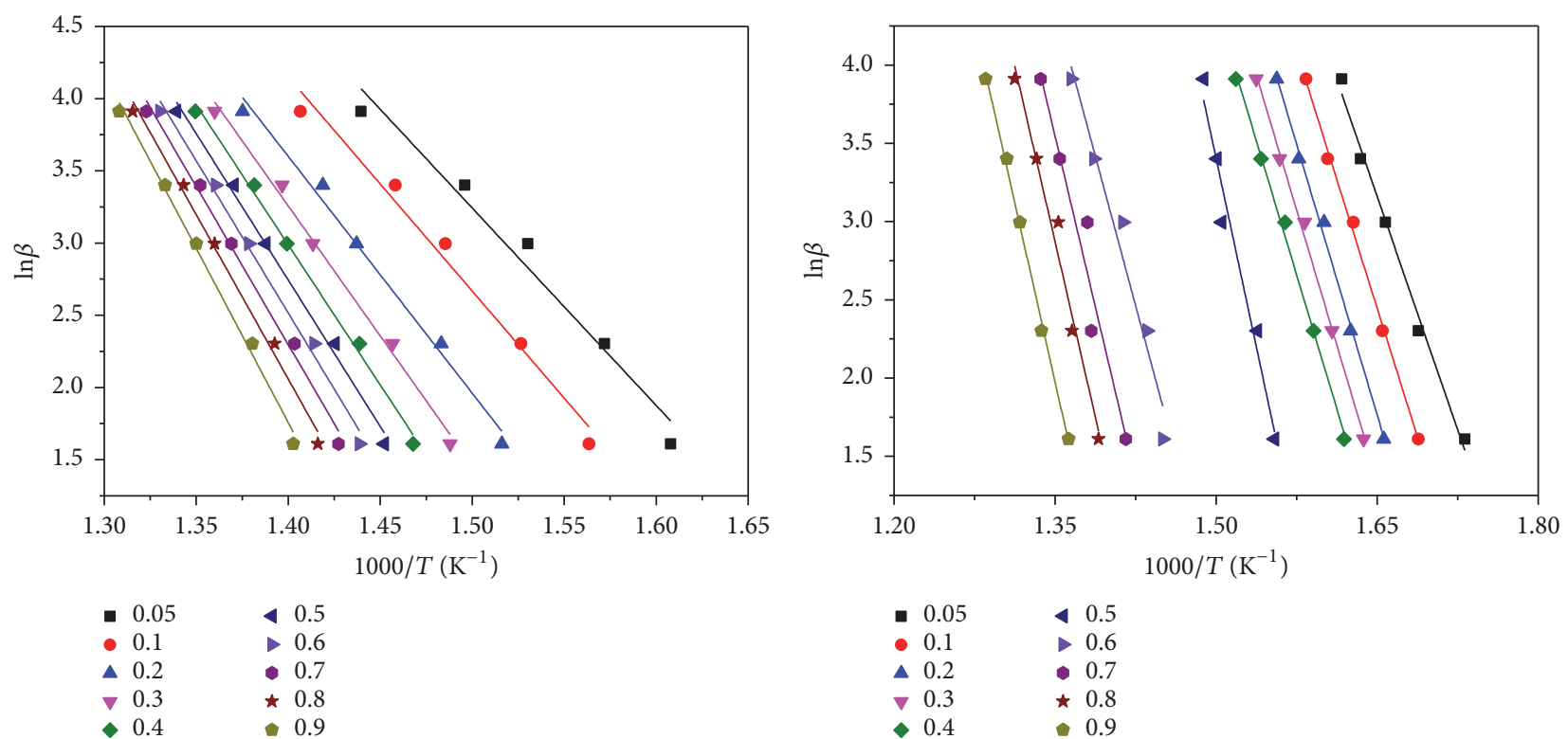

(a)
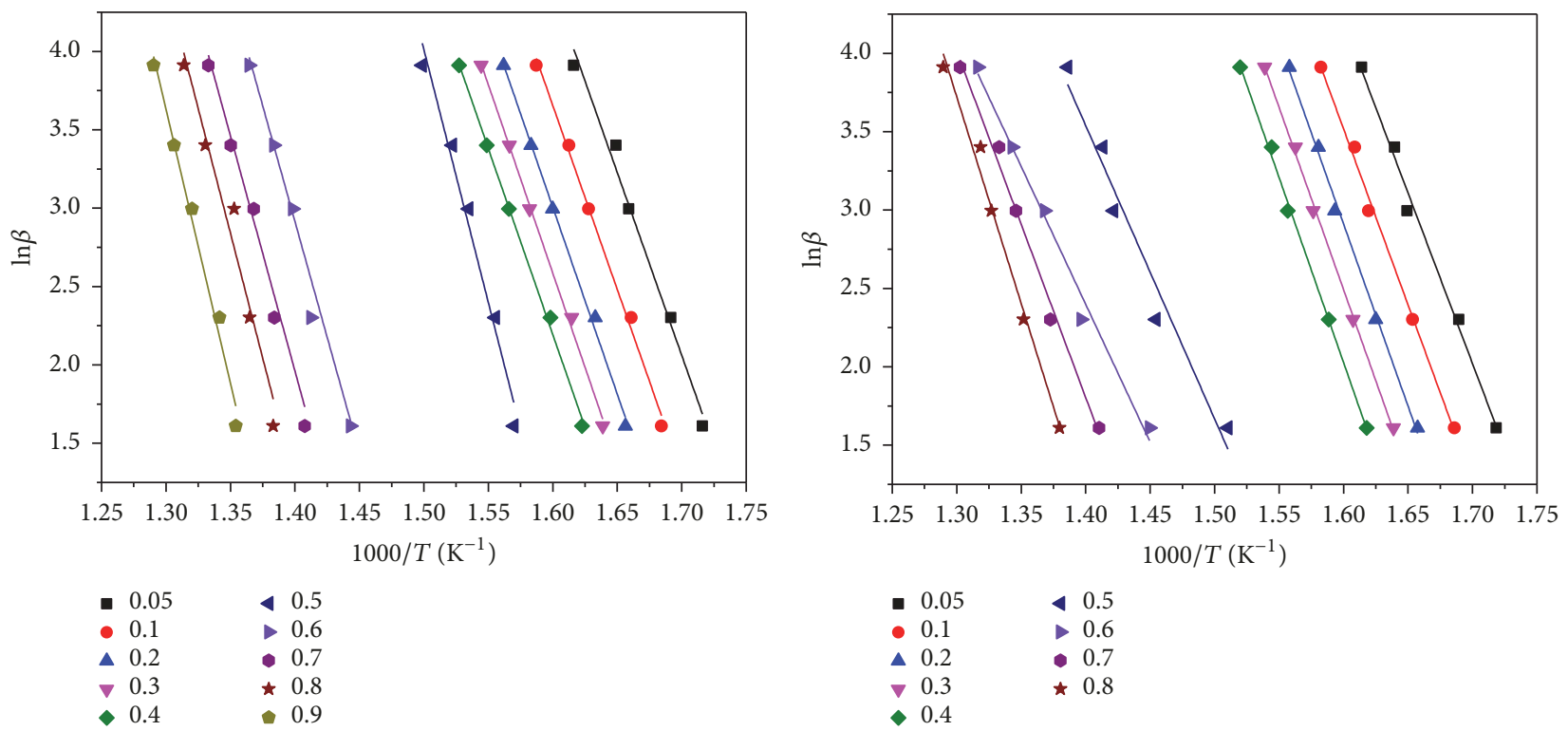

(c)

(d)

FIGURE 5: The curves of $\ln (\beta)-1000 / T$ of rPP and its composites: (a) pure rPP, (b) MCC/rPP (60/40), (c) MCC/PP-g-MA/rPP (60/5/35), (d) T-ZnOw/MCC/PP-g-MA/rPP (5/55/5/35).

3.6. Nonisothermal Crystallization Kinetics Analysis. The crystallization curves of rPP and its composites with different cooling rates are shown in Figure 6. When the cooling rate increased, the crystallization temperature $\left(T_{c}\right)$ of the $\mathrm{rPP}$ and its composites decreased and the crystallization peak broadened. This is because the activity of molecular chains weakened at low temperature. As a result, the samples could not crystallize completely leading to shortened crystallization time and low crystallization temperature.

It could be seen from Table 5 that $T_{\mathrm{c}}$ of $\mathrm{MCC} / \mathrm{rPP}$ composites was lower than that of the pure rPP at the same cooling rate. $T_{\mathrm{c}}$ of MCC/rPP composites shifted to a low temperature because MCC is a polar organic filler, whereas rPP resin is nonpolar. Interface incompatibility occurred when the two phases were melted and blended without any treatment. MCC could hinder the movement of rPP molecular chains and hinder the crystallization of $\mathrm{rPP}$, thereby causing the $T_{\mathrm{c}}$ to shift to a low temperature. $T_{c}$ of MCC/PP-g-MA/rPP (107.9$\left.120.3^{\circ} \mathrm{C}\right)$ was higher than $\mathrm{MCC} / \mathrm{rPP}\left(106.1-118.2^{\circ} \mathrm{C}\right)$. The presence of PP-g-MA improved the interface compatibility of the two phases. Therefore, in the crystallization process of the sample, MCC promoted the crystallization of rPP and acted as a nucleating agent.

Owing to the unique three-dimensional structure of T-ZnOw in T-ZnOw/MCC/ PP-g-MA/rPP composite, the needles of $\mathrm{T}-\mathrm{ZnO}$ w could be embedded in rPP matrix. A large 

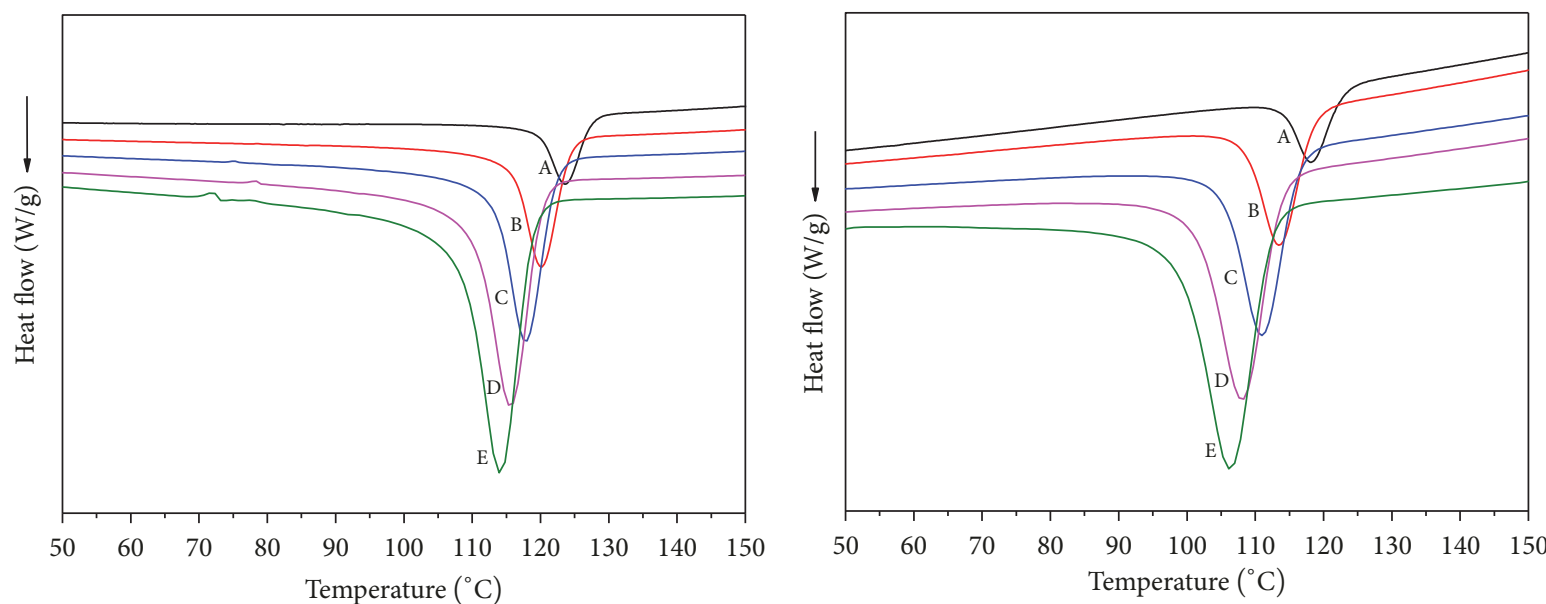
A. $10^{\circ} \mathrm{C} \cdot \mathrm{min}^{-1}$
B. $20^{\circ} \mathrm{C} \cdot \mathrm{min}^{-1}$
C. $30^{\circ} \mathrm{C} \cdot \mathrm{min}^{-1}$

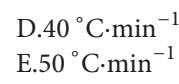

(a)

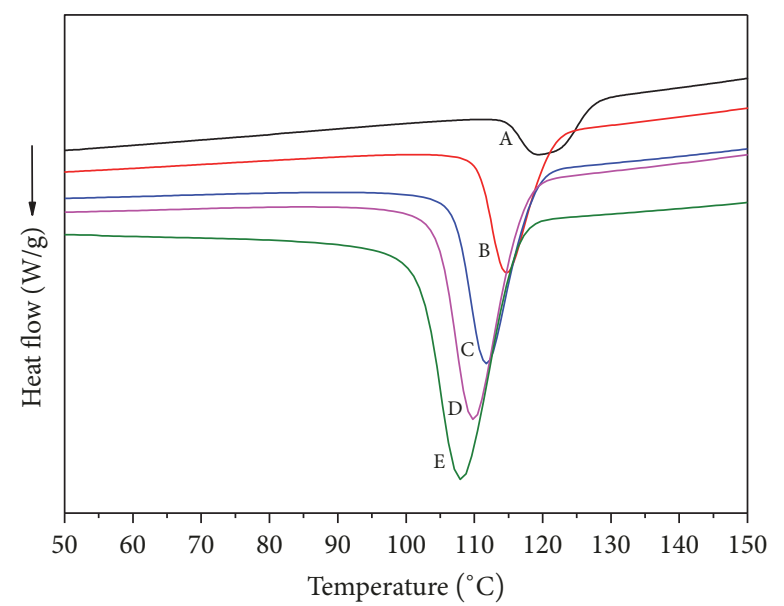

\section{A. $10^{\circ} \mathrm{C} \cdot \mathrm{min}^{-1}$ \\ B. $20^{\circ} \mathrm{C} \cdot \mathrm{min}^{-1}$ \\ D. $40^{\circ} \mathrm{C} \cdot \mathrm{min}^{-1}$ \\ E. $50^{\circ} \mathrm{C} \cdot \min ^{-1}$}

C. $30^{\circ} \mathrm{C} \cdot \mathrm{min}^{-1}$

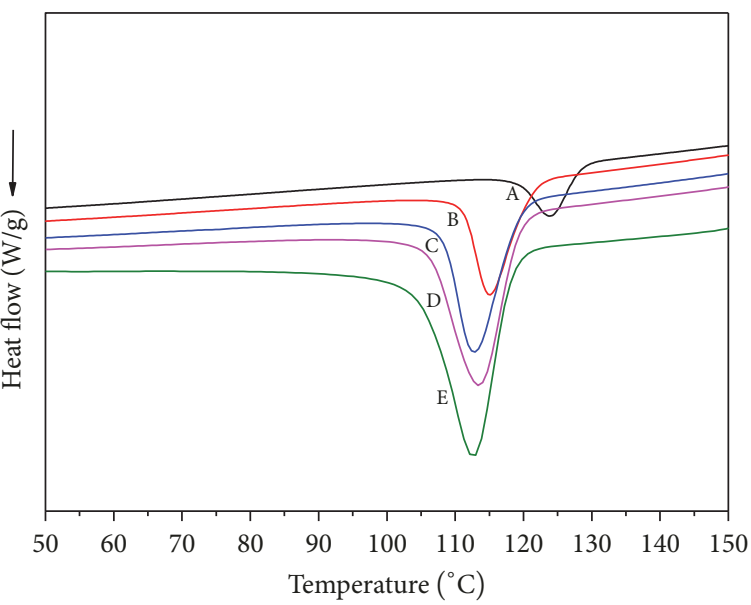

(b)
A. $10^{\circ} \mathrm{C} \cdot \mathrm{min}^{-1}$
B. $20^{\circ} \mathrm{C} \cdot \mathrm{min}^{-1}$
C. $30^{\circ} \mathrm{C} \cdot \mathrm{min}^{-1}$

(d)

Figure 6: The curves of rPP and its composites at different cooling rates: (a) pure rPP, (b) MCC/rPP (60/40), (c) MCC/PP-g-MA/rPP (60/5/35), (d) T-ZnOw/MCC/PP-g-MA/rPP (5/55/5/35).

steric hindrance of $\mathrm{T}-\mathrm{ZnOw}$ could promote the interaction with MCC and form a greater resistance to the activity of rPP molecular chains. T-ZnOw also played a role in $\mathrm{rPP}$ as a nucleating agent to promote $\mathrm{rPP}$ to form crystallization around fillers. $T_{c}\left(113.0-123.5^{\circ} \mathrm{C}\right)$ of $\mathrm{T}-\mathrm{ZnOw} / \mathrm{MCC} / \mathrm{PP}-\mathrm{g}-$ $\mathrm{MA} / \mathrm{rPP}$ composite was higher than that of the other two types of composites and close to that of pure rPP. Hence, the presence of $\mathrm{T}-\mathrm{ZnO}$ w could promote $\mathrm{PP}$ molecular chains to have a faster crystallization rate at a relatively high temperature. With only a small amount of $\mathrm{T}-\mathrm{ZnOw}$, the crystallization process was promoted, thereby preventing oversizing of the crystal size. Relatively high mechanical properties of $\mathrm{T}-\mathrm{ZnOw} / \mathrm{MCC} / \mathrm{PP}-\mathrm{g}-\mathrm{MA} / \mathrm{rPP}$ composite in the mechanical properties analysis confirmed this result.
Nonisothermal crystallization could be analyzed according to the cooling rate $\mathrm{dT} / \mathrm{dt}$. The improved Irvar equation of the isothermal crystallization kinetics can be applied to determine the nonisothermal crystallization kinetic constant $K$ and the Avrami exponent $n$. The Avrami equation is given by (5).

$$
1-X(t)=\exp \left(-K t^{n}\right)
$$

The kinetic constant $K$ is a key factor for the simulation of nonisothermal crystallization processes. In order to obtain results, the modified Avrami equation is adopted and the physical dimensions of the kinetic constants are set to $\mathrm{s}^{-1}$ 
TABLE 5: Nonisothermal crystallization parameters of pure rPP and $\mathrm{rPP}$ based composites.

\begin{tabular}{|c|c|c|c|c|c|c|c|}
\hline Samples & $\begin{array}{l}\text { Cooling rate } \\
\left({ }^{\circ} \mathrm{C} \cdot \mathrm{min}^{-1}\right) \\
\end{array}$ & $\begin{array}{c}\Delta H_{c} \\
\left(\mathrm{~J} \cdot \mathrm{g}^{-1}\right)\end{array}$ & $\begin{array}{c}T_{0} \\
\left({ }^{\circ} \mathrm{C}\right) \\
\end{array}$ & $\begin{array}{c}T_{\mathrm{c}} \\
\left({ }^{\circ} \mathrm{C}\right)\end{array}$ & $n$ & $\begin{array}{c}K \\
\left(\mathrm{~s}^{-1}\right) \\
\end{array}$ & $\begin{array}{c}t_{1 / 2} \\
(\mathrm{~min}) \\
\end{array}$ \\
\hline \multirow{5}{*}{$\mathrm{rPP}$} & 10 & 58.4 & 127.4 & 123.6 & 3.4 & 0.8 & 1.2 \\
\hline & 20 & 60.5 & 124.3 & 120.2 & 3.2 & 6.8 & 0.6 \\
\hline & 30 & 59.2 & 122.2 & 118.0 & 3.5 & 28.4 & 0.4 \\
\hline & 40 & 56.6 & 120.2 & 115.3 & 3.6 & 91.2 & 0.3 \\
\hline & 50 & 61.1 & 119.3 & 113.9 & 3.1 & 86.2 & 0.3 \\
\hline \multirow{5}{*}{$\mathrm{MCC} / \mathrm{rPP}$} & 10 & 60.2 & 122.2 & 118.2 & 3.9 & 1.5 & 0.7 \\
\hline & 20 & 62.3 & 118.5 & 113.4 & 4.2 & 9.7 & 0.5 \\
\hline & 30 & 60.0 & 116.3 & 111.0 & 4.1 & 38.7 & 0.4 \\
\hline & 40 & 57.0 & 113.8 & 108.3 & 3.6 & 64.9 & 0.3 \\
\hline & 50 & 62.8 & 112.4 & 106.1 & 3.3 & 54.6 & 0.3 \\
\hline \multirow{5}{*}{ MCC/PP-g-MA/rPP } & 10 & 64.6 & 126.4 & 120.2 & 3.5 & 0.7 & 0.9 \\
\hline & 20 & 72.6 & 120.9 & 114.7 & 3.9 & 11.2 & 0.4 \\
\hline & 30 & 72.0 & 118.3 & 111.7 & 3.3 & 18.2 & 0.3 \\
\hline & 40 & 72.3 & 116.8 & 109.7 & 3.8 & 113.9 & 0.3 \\
\hline & 50 & 74.9 & 116.2 & 107.9 & 3.6 & 112.9 & 0.2 \\
\hline \multirow{5}{*}{ T-ZnOw/MCC/PP-g-MA/rPP } & 10 & 57.4 & 128.3 & 123.4 & 3.5 & 1.5 & 0.8 \\
\hline & 20 & 72.3 & 121.0 & 115.1 & 3.6 & 9.2 & 0.6 \\
\hline & 30 & 69.4 & 119.3 & 113.9 & 4.1 & 42.7 & 0.3 \\
\hline & 40 & 67.4 & 119.0 & 113.3 & 3.9 & 96.0 & 0.3 \\
\hline & 50 & 70.0 & 118.4 & 112.9 & 4.0 & 129.8 & 0.2 \\
\hline
\end{tabular}

$[54,55]$. The change of the above equation to a linear form is given as

$$
\ln [-\ln (1-X(t))]=\ln K+n \ln t
$$

where $X(t)$ is the relative crystallinity; $K$ is the crystallization rate constant; and $n$ is the Avrami index.

The relationship between $X(\mathrm{t})$ and the crystallization time of rPP based composites at different cooling rates along with curves of $\ln [-\ln (1-X(\mathrm{t}))]$ vs. $\ln t$ is shown in Figure 7. It can be observed from Figures $7(\mathrm{a})$ and $7(\mathrm{~d})$ that the curves of relative $X(\mathrm{t})$ and crystallization time both had an " $\mathrm{S}$ " shape, which became smooth with a drop of rate. The shape of curves became sharp when temperature was dropped, which indicated that the crystallization time decreased with a fast drop in the temperature. The parameter of $t_{1 / 2}$ in Table 5 represented the time for the composite to complete $50 \%$ crystallization. The faster cooling rate worsened the activity of the polymer molecular chains, and the degree of crystal perfection was significantly reduced, which resulted in a shortened crystallization time.

It can be seen from Figures $7\left(a_{1}\right)-7\left(d_{1}\right)$ that $r P P$ and its composites both had a good linear relationship between $\ln [-\ln (1-X(\mathrm{t}))]$ and $\ln t$ at different cooling rates. The value of $n$ depended on the nucleation mechanism and the crystal growth mode, as well as the rate constant $K$ containing the nucleation and growth parameters. Results indicate that after improving the parameters of Avrami equation, it could be applied to rPP and its composites for nonisothermal crystallization kinetics analysis.

\section{Conclusion}

In this study, $\mathrm{T}-\mathrm{ZnOw}$ was filled into the MCC/PP-g$\mathrm{MA} / \mathrm{rPP}$ composite in order to improve the properties of the composite. Optimized composition of the composite for the best performance was T-ZnOw: MCC: PP-g-MA: rPP $=5: 55: 5: 35$. PP-g-MA improved the compatibility between fillers and matrix. Synergistic effect of T-ZnOw and MCC led to an enhancement of the mechanical performances. Thermal analysis and thermal degradation activation energy suggest that $\mathrm{T}-\mathrm{ZnOw}$ improved the initial degradation temperature and maximum weight loss temperature of the composite. Effect of $\mathrm{T}-\mathrm{ZnOw}$ on the crystallization behavior of the composite could be clearly observed from the nonisothermal crystallization kinetics. The presence of $\mathrm{T}-\mathrm{ZnOw}$ promoted the crystallization of the matrix at a relatively high temperature and MCC acted as a nucleating agent during the crystallization, which resulted in the increase of the crystallization rate of the composite.

\section{Data Availability}

The data used to support the findings of this study are available from the corresponding author upon request. 


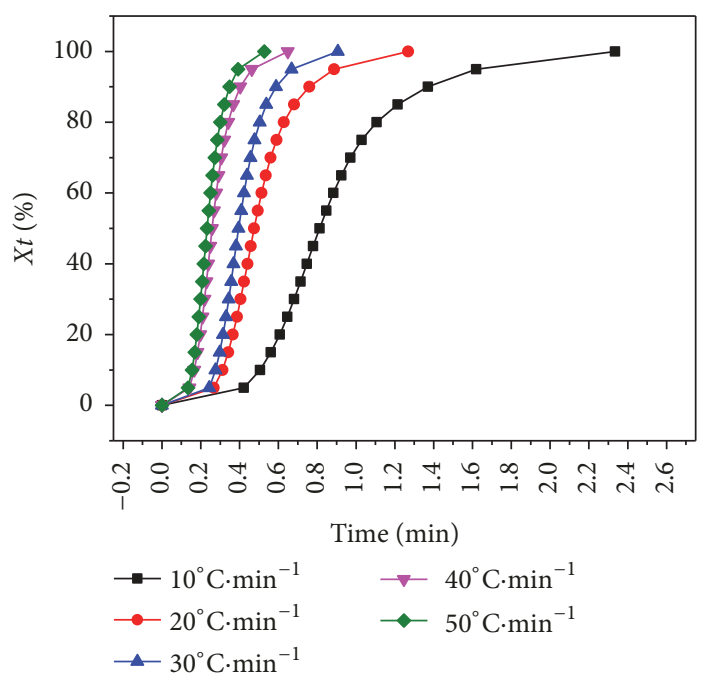

(a)

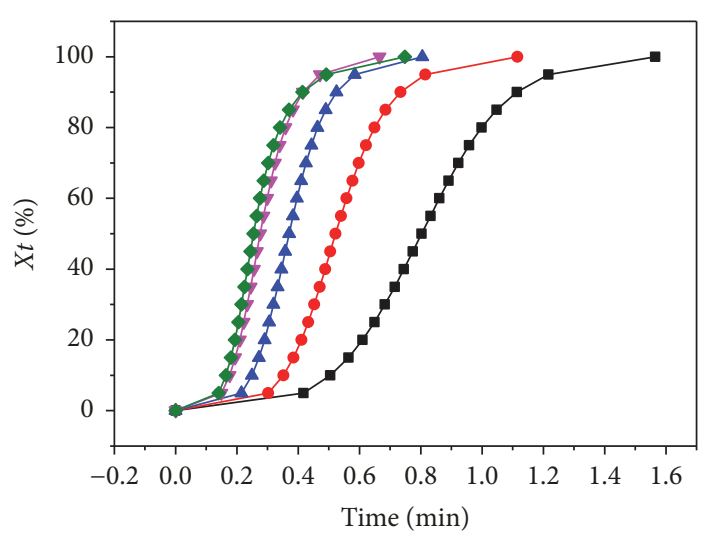

$$
\begin{array}{ll}
\rightarrow 10^{\circ} \mathrm{C} \cdot \mathrm{min}^{-1} & \rightarrow 40^{\circ} \mathrm{C} \cdot \mathrm{min}^{-1} \\
\rightarrow 20^{\circ} \mathrm{C} \cdot \mathrm{min}^{-1} & \rightarrow 50^{\circ} \mathrm{C} \cdot \mathrm{min}^{-1} \\
\longrightarrow 30^{\circ} \mathrm{C} \cdot \mathrm{min}^{-1} &
\end{array}
$$

(b)

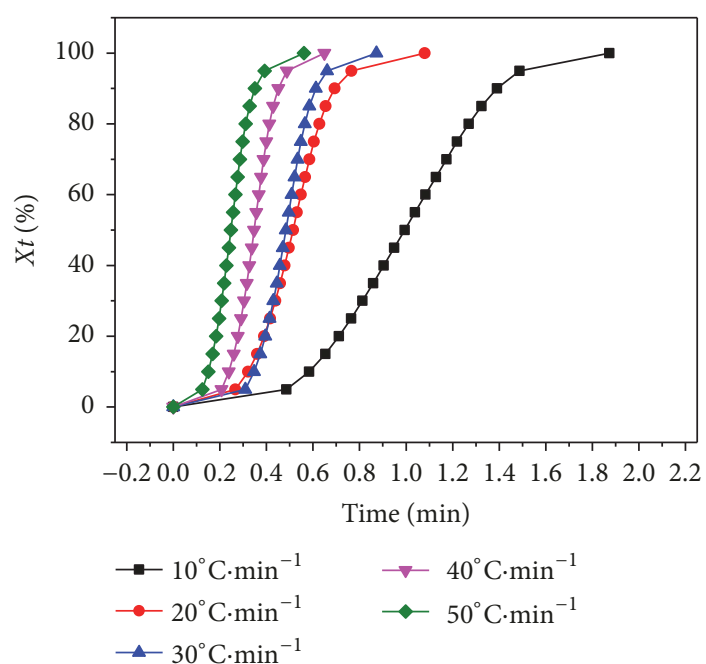

(c)

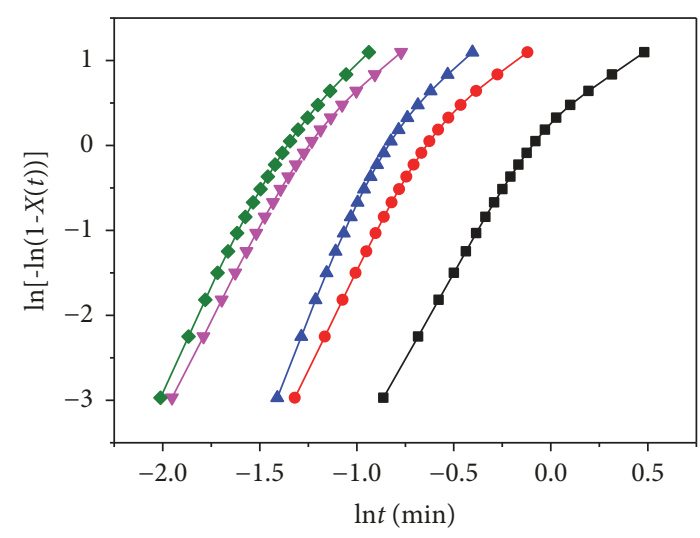

$$
\begin{aligned}
& \rightarrow-10^{\circ} \mathrm{C} \cdot \mathrm{min}^{-1} \quad \rightarrow \quad 40^{\circ} \mathrm{C} \cdot \mathrm{min}^{-1} \\
& \rightarrow 20^{\circ} \mathrm{C} \cdot \mathrm{min}^{-1} \quad \longrightarrow 50^{\circ} \mathrm{C} \cdot \mathrm{min}^{-1} \\
& \simeq 30^{\circ} \mathrm{C} \cdot \mathrm{min}^{-1}
\end{aligned}
$$

$\left(a_{1}\right)$

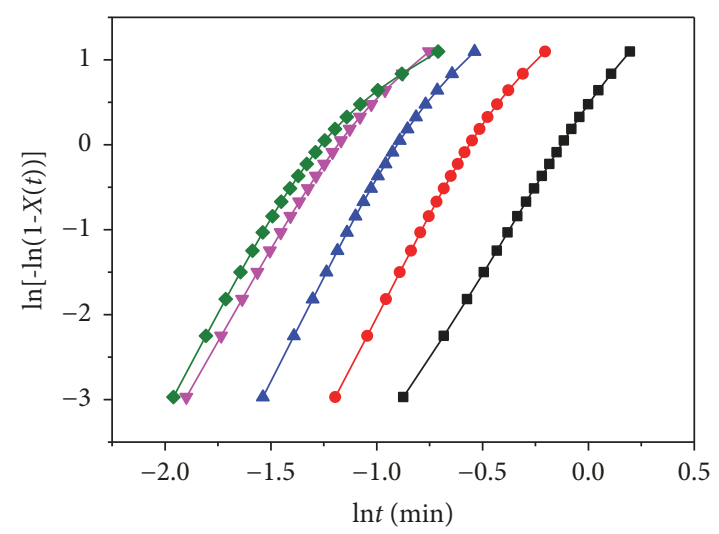

$$
\begin{array}{ll}
\rightarrow-10^{\circ} \mathrm{C} \cdot \mathrm{min}^{-1} & \rightarrow 40^{\circ} \mathrm{C} \cdot \mathrm{min}^{-1} \\
\rightarrow-20^{\circ} \mathrm{C} \cdot \mathrm{min}^{-1} & \rightarrow 50^{\circ} \mathrm{C} \cdot \mathrm{min}^{-1} \\
\longrightarrow 30^{\circ} \mathrm{C} \cdot \mathrm{min}^{-1} &
\end{array}
$$

$\left(b_{1}\right)$

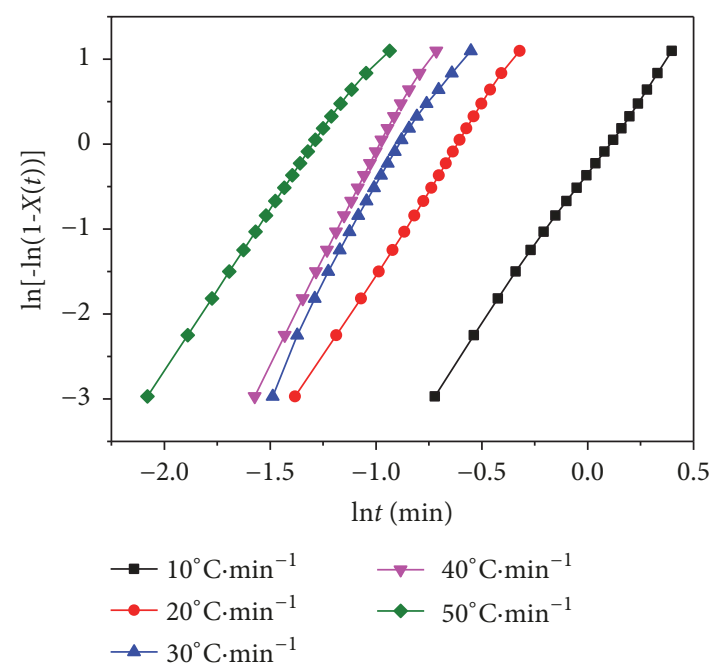

$\left(c_{1}\right)$

Figure 7: Continued. 


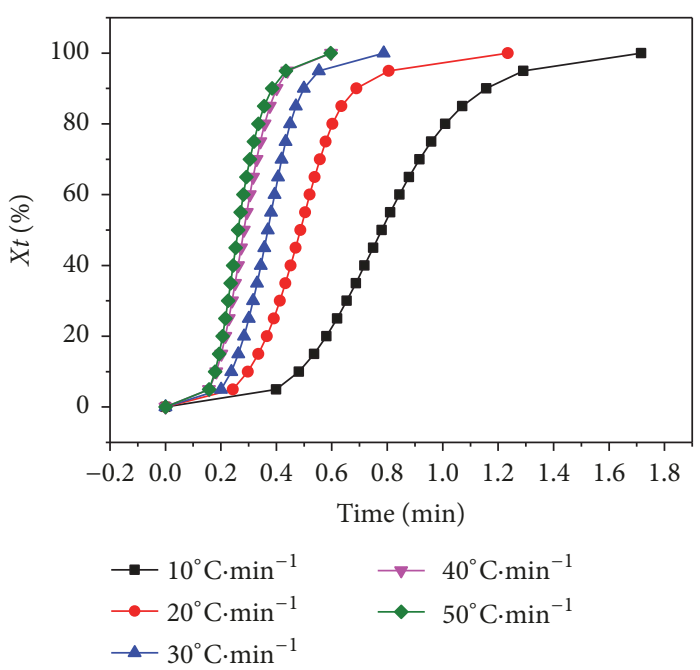

(d)

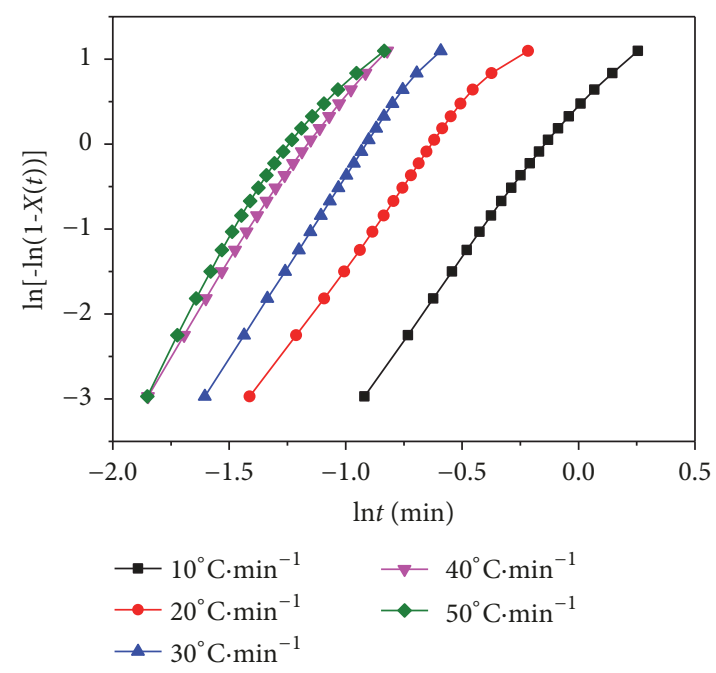

$\left(\mathrm{d}_{1}\right)$

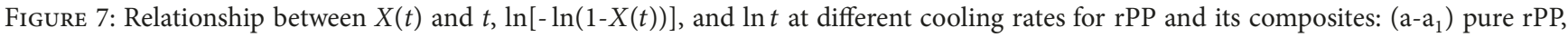
(b-b 1 ) MCC/rPP (60/40), (c-c $)$ MCC/PP-g-MA/rPP (60/5/35), (d-d d $\left._{1}\right)$ T-ZnOw/MCC/PP-g-MA/rPP (5/55/5/35).

\section{Conflicts of Interest}

The authors declare that they have no conflicts of interest.

\section{References}

[1] K. Rukmini, R. Bommulu, S. K. Shetty, A. Taraiya, S. Bandyopadhyay, and S. Hatna, "Development of eco-friendly cotton fabric reinforced polypropylene composites: mechanical, thermal, and morphological properties," Advances in Polymer Technology, vol. 32, no. 1, pp. 4186-4193, 2013.

[2] M. A. L. Manchado, L. Valentini, J. Biagiotti, and J. M. Kenny, "Thermal and mechanical properties of single-walled carbon nanotubes-polypropylene composites prepared by melt processing," Carbon, vol. 43, no. 7, pp. 1499-1505, 2005.

[3] X. J. Wang, P. Zhang, and R. Y. Hong, "Preparation and application of aluminum-doped zinc oxide powders via precipitation and plasma processing method," Journal of Applied Polymer Science, vol. 132, no. 22, pp. 351-357, 2015.

[4] J. C. Zhao, Q. L. Zhao, C. D. Wang, B. Guo, C. B. Park, and G. L. Wang, "High thermal insulation and compressive strength polypropylene foams fabricated by high-pressure foam injection molding and mold opening of nano-fibrillar composites," Materials \& Design, vol. 131, pp. 1-11, 2017.

[5] D. X. Sun, C. J. Yang, X. D. Qi, J. H. Yang, and Y. Wang, "Largely enhanced fracture toughness of the PP/EPDM blends induced by adding carbon nanofibers," Composites Science and Technology, vol. 164, pp. 146-152, 2018.

[6] M. Grala, Z. Bartczak, and A. Różański, "Morphology, thermal and mechanical properties of polypropylene/SiO2 nanocomposites obtained by reactive blending," Journal of Polymer Research, vol. 23, no. 2, pp. 1-19, 2016.

[7] P. Rachtanapum, S. E. M. Selke, and L. M. Matuana, "Relationship between cell morphology and impact strength of microcellular foamed high-density polyethylene/polypropylene blends," Polymer Engineering and Science, vol. 44, no. 8, pp. 1551$1560,2004$.
[8] A. Nourbakhsh, A. Ashori, H. Ziaei Tabari, and F. Rezaei, "Mechanical and thermo-chemical properties of wood-flour/ polypropylene blends," Polymer Bulletin, vol. 65, no. 7, pp. 691700, 2010.

[9] S. P. Bao and S. C. Tjong, "Temperature and strain rate dependences of yield stress of polypropylene composites reinforced with carbon nanofibers," Polymer Composites, vol. 30, no. 12, pp. 1749-1760, 2009.

[10] O. Ammar, Y. Bouaziz, N. Haddar, and N. Mnif, "Talc as reinforcing filler in polypropylene compounds: effect on morphology and mechanical properties," Polymer Science U S S R, vol. 3, no. 2, 2017.

[11] B. Fiorentino, R. Fulchiron, V. Bounor-Legaré, J.-C. Majesté, J. C. Leblond, and J. Duchet-Rumeau, "Chemical modification routes of synthetic talc: influence on its nucleating power and on its dispersion state," Applied Clay Science, vol. 109-110, pp. 107-118, 2015.

[12] F. Qiu, M. Wang, Y. Hao, and S. Guo, "The effect of talc orientation and transcrystallization on mechanical properties and thermal stability of the polypropylene/talc composites," Composites Part A, vol. 58, pp. 7-15, 2014.

[13] C. M. Chan, J. Wu, J. X. Li, and Y. K. Cheung, "Polypropylene/calcium carbonate nanocomposites," Polymer, vol. 43, no. 10, pp. 2981-2992, 2002.

[14] Q. C. Lu and Q. Dou, "Investigation on microstructures, melting and crystallization behaviors, mechanical and processing properties of $\beta$-isotactic polypropylene $/ \mathrm{CaCO} 3$ toughening masterbatch composites," Journal of Polymer Research, vol. 24, no. 11, 206 pages, 2017.

[15] Q. Wang, B. Liu, C. Huang, and X. Sun, "Study of rheological behavior of calcium carbonate filled polypropylene in dynamic extrusion," Advanced Materials Research, vol. 1053, no. 4, pp. 231-234, 2014.

[16] M. Salama, A. G. Hassabo, A. A. Elsayed, T. Salem, and C. Popescu, "Reinforcement of polypropylene composites based on recycled wool or cotton powders," Journal of Natural Fibers, vol. 14, no. 6, pp. 823-836, 2017. 
[17] A. A. Morandim-Giannetti, J. A. Agnelli, B. Z. Lanças, R. Magnabosco, S. A. Casarin, and S. H. Bettini, "Lignin as additive in polypropylene/coir composites: thermal, mechanical and morphological properties," Carbohydrate Polymers, vol. 87, no. 4, pp. 2563-2568, 2012.

[18] A. M. Jiménez, F. X. Espinach, L. A. Granda et al., "Tensile strength assessment of injection-molded high yield sugarcane bagasse-reinforced polypropylene," Bioresources, vol. 11, no. 3, 2016.

[19] S. M. Luz, A. R. Gonalves, A. P. Del et al., "Thermal properties of polypropylene composites reinforced with different vegetable fibers," Advanced Materials Research, vol. 123-125, pp.1199-1202, 2010.

[20] P. K Aggarwal, N. Raghu, A. Karmarkar, and S. Chuahan, "Jute-polypropylene composites using m-TMI-graftedpolypropylene as a coupling agent," Materials and Design, vol. 43, pp. 112-117, 2013.

[21] H. Essabir, M. O. Bensalah, D. Rodrigue, R. Bouhfid, and A. Qaiss, "Structural, mechanical and thermal properties of biobased hybrid composites from waste coir residues: Fibers and shell particles," Mechanics of Materials, vol. 93, pp. 134-144, 2016.

[22] H. S. Yang, H. J. Kim, J. Son et al., "Rice-husk flour filled polypropylene composites; mechanical and morphological study," Composite Structures, vol. 63, no. 3-4, pp. 305-312, 2004.

[23] K. A. Iyer, A. M. Flores, and J. M. Torkelson, "Comparison of polyolefin biocomposites prepared with waste cardboard, microcrystalline cellulose, and cellulose nanocrystals via solidstate shear pulverization," Polymer, vol. 75, pp. 78-87, 2015.

[24] N. I. Zulkifli, N. Samat, H. Anuar, and N. Zainuddin, "Mechanical properties and failure modes of recycled polypropylene/ microcrystalline cellulose composites," Materials and Design, vol. 69, pp. 114-123, 2015.

[25] H. S. Yang, D. J. Gardner, and J. W. Nader, "Morphological properties of impact fracture surfaces and essentialwork of fracture analysis of cellulose nanofibril-filled polypropylenecomposites," Journal of Applied Polymer Science, vol. 128, pp. 3064-3076, 2013.

[26] A. A. Morandim-Giannettia, J. A. M. Agnellib, B. Z. Lance, R. Magnaboscoc, S. A. Casarinb, and S. H. P. Bettini, "Lignin as additive in polypropylene/coir composites: thermal, mechanical and morphological properties," Carbohydrate Polymers, vol. 87, no. 4, pp. 2563-2568, 2012.

[27] A. Kiziltas, D. J. Gardner, Y. Han, and H.-S. Yang, "Mechanical Properties of Microcrystalline Cellulose (MCC) filled engineering thermoplastic composites," Journal of Polymers and the Environment, vol. 22, no. 3, pp. 365-372, 2014.

[28] A. Zeng, Y. Zheng, Y. Guo, S. Qiu, and L. Cheng, "Effect of tetraneedle-shaped zinc oxide whisker (T-ZnOw) on mechanical properties and crystallization behavior of isotactic polypropylene," Materials and Design, vol. 34, pp. 691-968, 2012.

[29] J. R. Liu, Z. Sun, and Q. Yu, "Effects of stearic acid on rheology and crystallization of nano-zno filled polypropylene," Journal of Chemical Engineering of Chinese Universities, 2016.

[30] M. Li, G. Li, J. Jiang, Y. Tao, and K. Mai, "Preparation, antimicrobial, crystallization and mechanical properties of nano$\mathrm{ZnO}$-supported zeolite filled polypropylene random copolymer composites," Composites Science and Technology, vol. 81, no. 15, pp. 30-36, 2013.

[31] X. C. Wang, R. F. Song, Y. J. Chen, Y. H. Zhao, K. Y. Zhu, and X. Y. Yuan, "Mechanical properties of polypropylene by diversely compatibilizing with titanate whiskers in composites," Composites Science \& Technology, 2018.

[32] L. Dang, X. Nai, X. Liu, D. Zhu, and Y. Dong, "Mechanical and flame retardant properties of isotactic polypropylene/magnesium oxysulfate whisker composite," Journal of Thermoplastic Composite Materials, vol. 31, no. 4, pp. 514-534, 2018.

[33] B. He, X. F. Lin, and Y. F. Zhang, "Effect of a novel compound nucleating agent calcium sulfate whisker/beta-nucleating agent dicyclohexyl-terephthalamide on crystallization and melting behavior of isotactic polypropylene," Journal of Thermal Analysis and Calorimetry, vol. 132, no. 2, pp. 1145-1152, 2018.

[34] L. N. Niu, M. Fang, K. Jiao et al., "Tetrapod-like zinc oxide whisker enhancement of resin composite," Journal of Dental Research, vol. 89, no. 7, pp. 746-750, 2010.

[35] J. F. Jin, W. Y. Liu, W. Y. Zhang et al., "Nano-ZnO/ZnO-HAPw prepared via sol-gel method and antibacterial activities of inorganic agents on six bacteria associated with oral infections," Journal of Nanoparticle Research, vol. 16, no. 10, article 2658, 2014.

[36] K. Chen, C. X. Xiong, L. B. Li, L. Zhou, Y. A. Lei, and L. J. Dong, "Conductive mechanism of antistatic poly(ethylene terephthalate)/ZnOw composites," Polymer Composites, vol. 30, no. 2, pp. 226-231, 2010.

[37] Z. W. Zhou, S. Hu, and L. S. Chu, "Studies on tetrapod-shaped $\mathrm{ZnO}$ whisker modified polymer composites," Materials Science Forum, vol. 475-479, pp. 1033-1036, 2005.

[38] S. B. Zhu, M. Jiang, J. H. Qiu, Z. W. Zhou, Y. Wang, and X. M. Fan, "Theoretical analysis of fracture of tetra-needle-like $\mathrm{ZnO}$ whisker in polymer composite," Journal of Applied Polymer Science, vol. 120, no. 5, pp. 2767-2771, 2011.

[39] G. M. Shashidhara, D. Biswas, B. S. Pai, A. K. Kadiyala, G. S. W. Feroze, and M. Ganesh, "Effect of PP-g-MAH compatibilizer content in polypropylene/nylon-6 blends," Polymer Bulletin, vol. 63, no. 1, pp. 147-157, 2009.

[40] C. Ihemouchen, H. Djidjelli, A. Boukerrou, F. Fenouillot, and C. Barres, "Effect of compatibilizing agents on the mechanical properties of high-density polyethylene/olive husk flour composites," Journal of Applied Polymer Science, vol. 128, no. 3, pp. 2224-2229, 2013.

[41] M. Asim, M. T. Paridah, N. Saba et al., "Thermal, physical properties and flammability of silane treated kenaf/pineapple leaf fibres phenolic hybrid composites," Composite Structures, vol. 202, pp. 1330-1338, 2018.

[42] A. V. Rajulu, K. N. Chary, G. R. Reddy, Y. Z. Meng, and J. Reinf, "Void content, density and weight reduction studies on short bamboo fiber-epoxy composites," Journal of Reinforced Plastics and Composites, vol. 23, no. 2, pp. 127-130, 2004.

[43] M. Jawaid, H. A. Khalil, A. A. Bakar, and P. N. Khanam, "Chemical resistance, void content and tensile properties of oil palm/jute fibre reinforced polymer hybrid composites," Materials \& Design, vol. 32, no. 2, pp. 1014-1019, 2011.

[44] H. Osman, H. Ismail, and M. Mustapha, "Effects of maleic anhydride polypropylene on tensile, water absorption, and morphological properties of recycled newspaper filled polypropylene/natural rubber composites," Journal of Composite Materials, vol. 44, no. 12, pp. 1477-1491, 2010.

[45] Z. Lin, C. Chen, Z. Guan, S. Tan, and X. Zhang, "A compatibilized composite of recycled polypropylene filled with cellulosic fiber from recycled corrugated paper board: mechanical properties, morphology, and thermal behavior," Journal of Applied Polymer Science, vol. 122, pp. 2789-2797, 2011. 
[46] X. Zhang, J. Shen, H. Yang, Z. Lin, and S. tan, "Mechanical properties, morphology, thermal performance, crystallization behavior, and kinetics of $\mathrm{PP} /$ microcrystal cellulose composites compatibilized by two different compatibilizers," Journal of Thermoplastic Composite Materials, vol. 24, no. 6, pp. 735-753, 2011.

[47] W. L. Qiu, F. R. Zhang, T. Endo, and T. Hirotsu, "Effect of maleated polypropylene on performance of polypropylene/ cellulose composite," Polymer Composites, vol. 26, no. 4, pp. 448-453, 2010.

[48] J. Wang, J. F. Tung, M. Y. A. Fuad, and P. R. Hornsby, "Microstructure and mechanical properties of ternary phase polypropylene/elastomer/magnesium hydroxide fire-retardant compositions," Journal of applied polymer science, vol. 60, no. 9, pp. 1425-1437, 1996.

[49] Y. Wang, J. Shi, L. Han, and F. Xiang, "Crystallization and mechanical properties of T-ZnOw/HDPE composites," Materials Science and Engineering A, vol. 501, no. 1, pp. 220-228, 2009.

[50] B. Y. Wen and B. B. Ji, "Crystallization behaviors and mechanical performance of polypropylene/tetrapod-shaped zinc oxide whisker composites," Journal of Applied Polymer Science, vol. 124, no. 1, p. 138, 2012.

[51] A. C. De Albuquerque, K. Joseph, L. H. De Carvalho, and J. R. M. DAlmeida, "Effect of wettability and ageing conditions on the physical and mechanical properties of uniaxially oriented jute-roving-reinforced polyester composites," Composites Science and Technology, vol. 60, no. 6, pp. 833-844, 2000.

[52] P. S. Chua, S. R. Dai, and M. R. Piggott, "Mechanical properties of the glass fibre-polyester interphase," Journal of Materials Science, vol. 27, no. 4, pp. 913-918, 1992.

[53] A. A. Morandim-Giannetti, J. A. M. Agnelli, B. Z. Lanças, R. Magnabosco, S. A. Casarin, and S. H. P. Bettini, "Lignin as additive in polypropylene/coir composites: Thermal, mechanical and morphological properties," Carbohydrate Polymers, vol. 87, no. 4, pp. 2563-2568, 2012.

[54] A. Maffezzoli, J. Kenny, and L. Torre, "On the physical dimensions of the Avrami constant," Thermochimica Acta, vol. 269270, pp. 185-190, 1995.

[55] A. Greco and A. Maffezzoli, "Analysis of the suitability of poly(lactic acid) in rotational molding process," Advances in Polymer Technology, vol. 34, no. 3, 2015. 


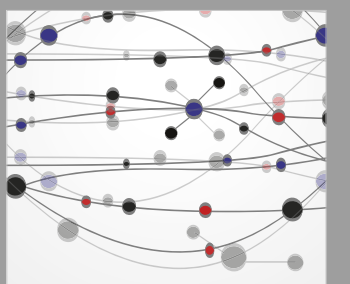

The Scientific World Journal
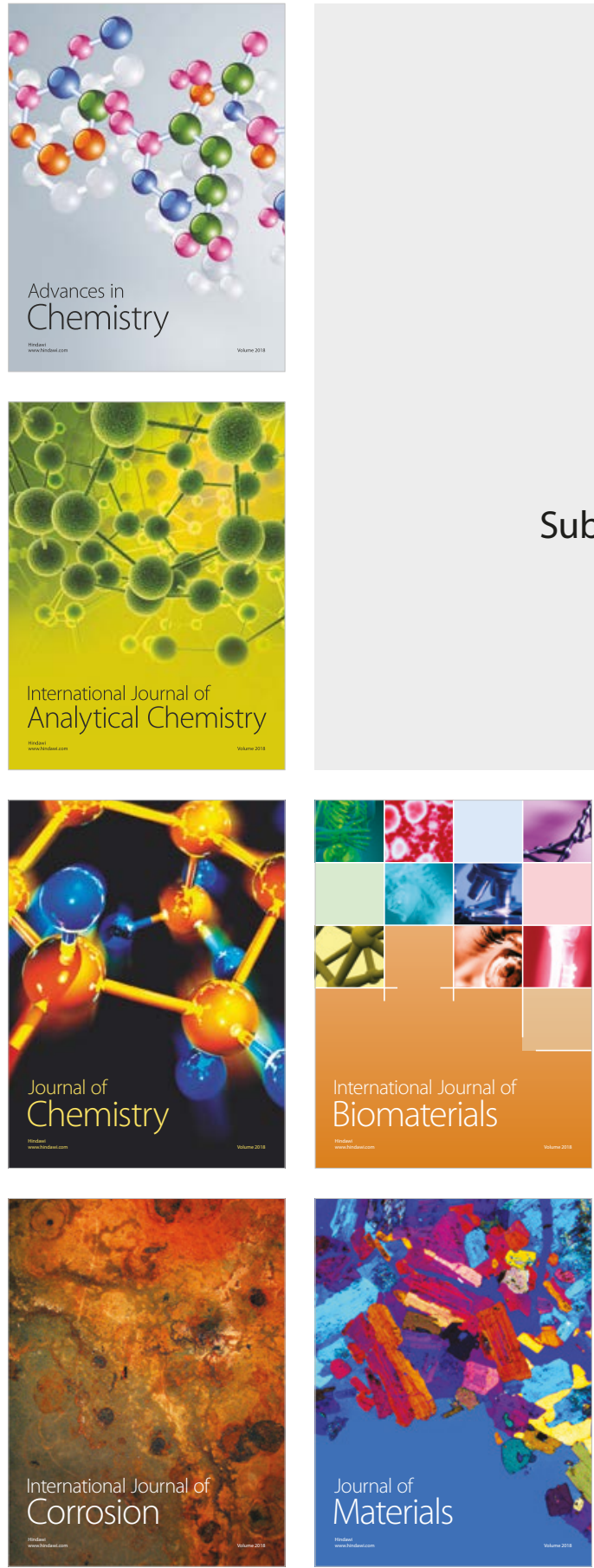

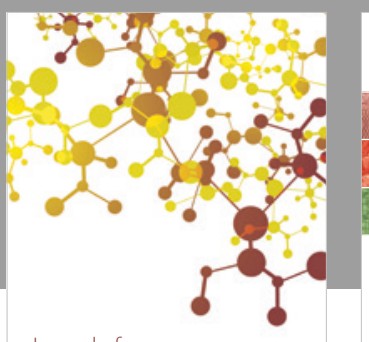

Journal of

Applied Chemistry
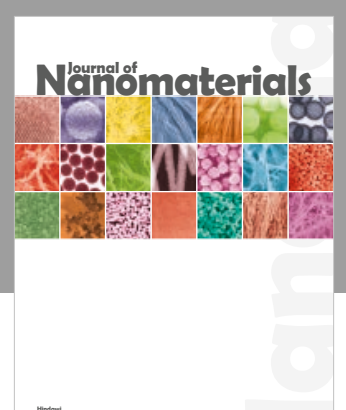

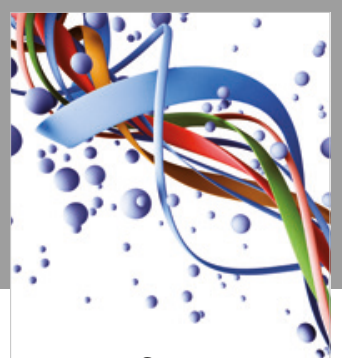

Scientifica

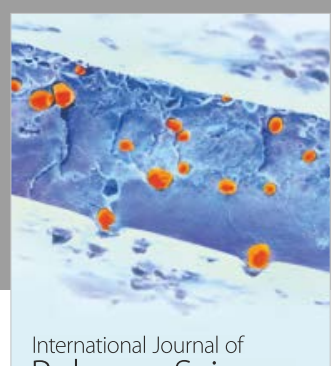

Polymer Science

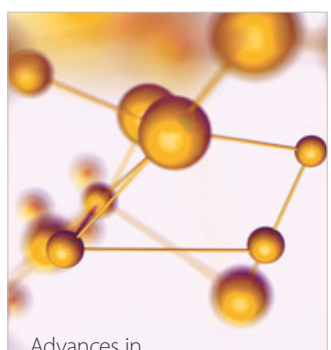

Physical Chemistry
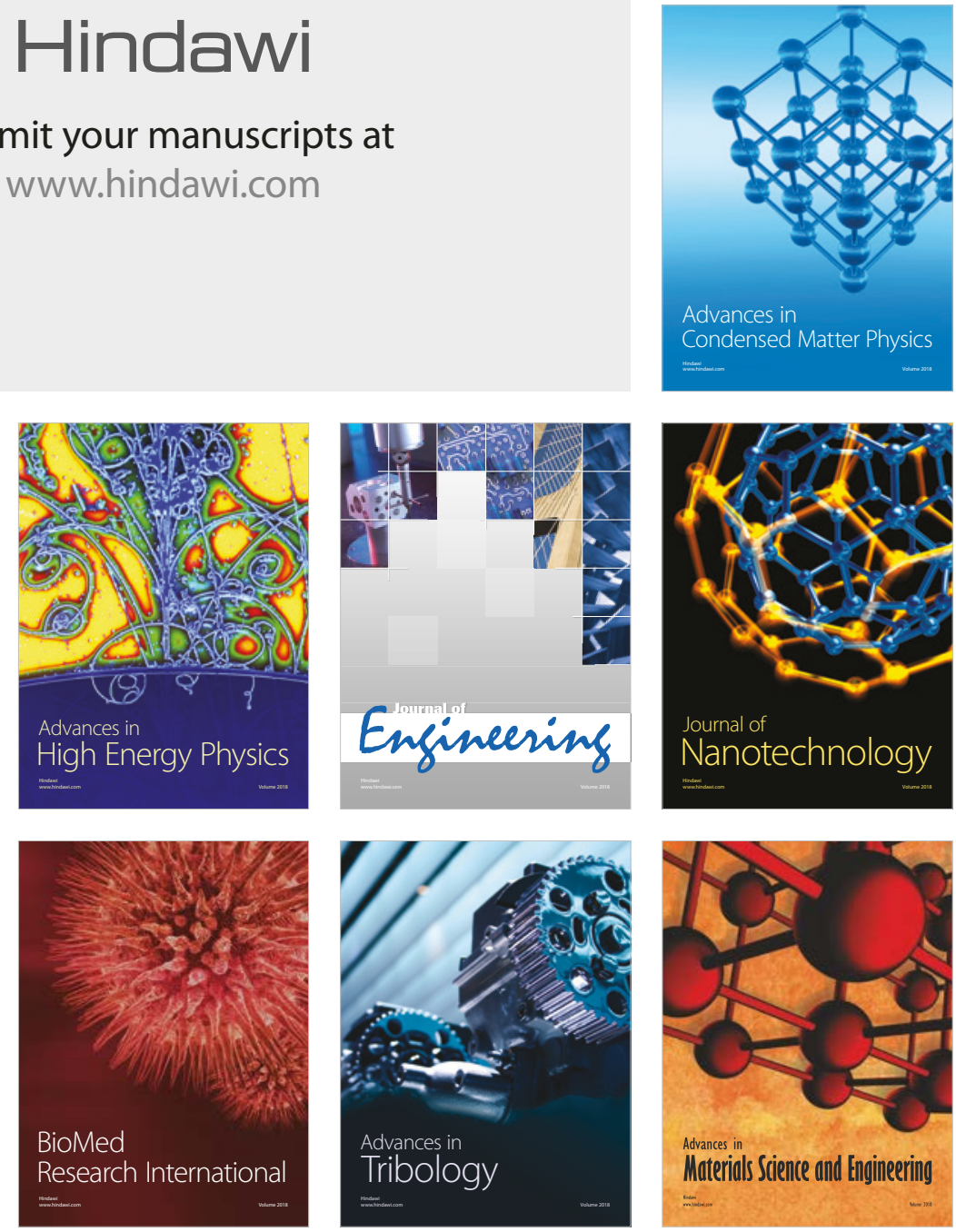